\title{
La acción de no discriminación arbitraria a la luz de la tutela judicial efectiva
}

\author{
The non-arbitrary discrimination action in light of \\ effective judicial protection
}

\author{
Gaspar Jenkins Peña y Lillo ${ }^{1}$ \\ Universidad del Desarrollo \\ gjenkins@udd.cl
}

\begin{abstract}
Resumen: El presente trabajo revisa de forma crítica el procedimiento instaurado por la Ley Zamudio para el conocimiento de la acción de no discriminación, a la luz de los parámetros materiales que emanan del derecho a la tutela judicial efectiva. Para ello, primeramente, revisaremos e identificaremos cuáles serán aquellos presupuestos sustanciales del derecho fundamental a la tutela judicial, para luego, conforme a ellos, dar paso al examen del procedimiento en concreto, siempre bajo la lógica de comprobar si aquel es eficaz en su rol de tutelar un derecho fundamental.
\end{abstract}

Palabras clave: Tutela judicial efectiva, acción de no discriminación ar-

1 Profesor de derecho constitucional e investigador del Centro de Justicia Constitucional de la Universidad del Desarrollo. Magíster en Derecho, LLM, de la Pontificia Universidad Católica de Chile. Licenciado en Ciencias Jurídicas y Sociales de la Universidad Católica del Norte. Miembro de la Asociación Chilena de Derecho Constitucional. Correo electrónico: gjenkins@udd.cl. Agradezco las lúcidas observaciones realizadas a este trabajo por los destacados profesores Marisol Peña Torres, Kamel Cazor Aliste, José Manuel Díaz de Valdés Julíe, Rodrigo Pica Flores, Gonzalo Cortés Moreno, y Diego MiRAnda ReYes, así como también aquellas dadas por los árbitros evaluadores, sin las cuales la presente investigación no habría sido posible. 
bitraria, Ley Zamudio, derecho antidiscriminatorio, garantía de derechos fundamentales.

\begin{abstract}
The following work critically reviews the procedure established by the Zamudio Law regarding the lodging of the non-discrimination action, in light of the material parameters that originate from the right to effective judicial protection. For that purpose, firstly, we shall review and identify those which are the substantial premises of the fundamental right to judicial protection, so as to later, according to these, give way to a concrete examination of the procedure, always within the logic of verifying if it is effective in its role of protecting a fundamental right.
\end{abstract}

Keywords: Effective judicial protection, non-discrimination action, Zamudio Law, antidiscrimination law, guarantee of fundamental rights.

\title{
1. Introducción
}

En el año 2012 se publicó la Ley N²0.609, que "establece medidas contra la discriminación" -también conocida como "Ley Zamudio"-, con el objeto de suplir un vacío legislativo que, hasta ese momento, existía en el ordenamiento jurídico nacional sobre el derecho antidiscriminatorio. De esta forma, la ley contempló instituciones novedosas para el panorama normativo de la época (como intentar dar una definición legal de discriminación arbitraria ${ }^{2}$, o configurar una agravante penal para aquellos delitos cometidos con motivos de "odio"3), dentro de las cuales destacó la creación de una nueva acción judicial, destinada a proteger a las personas frente a actos $u$ omisiones que signifiquen una discriminación arbitraria en su contra.

La acción de no discriminación arbitraria, a pesar de su nombre, se muestra como una acción amplia, cuyo objeto es proteger el ejercicio legítimo de los derechos fundamentales ${ }^{4}$ de toda persona, contra pertur-

2 Artículo $2^{\circ}$ de la Ley $N^{\circ} 20.609$.

3 Artículo 17 de la Ley №20.609.

4 Establecidos en la Constitución Política o en tratados internacionales sobre derechos humanos ratificados por Chile y que se encuentren vigentes, según el artículo $2^{\circ}$ de la Ley $\mathrm{N}^{\circ} 20.609$. 
baciones, privaciones o amenazas producidas por algún acto u omisión que se traduzcan, especialmente, en una distinción, exclusión o restricción que carezca de una justificación razonable. Como toda acción jurisdiccional, su consagración entrega a las personas la facultad de acudir a los Tribunales, solicitando una tutela reactiva ante casos en que se ha lesionado el derecho a no ser discriminado arbitrariamente ${ }^{5}$-o preventiva, cuando el derecho se ve amenazado-, dando con ello origen a un procedimiento judicial cuyas reglas se encuentran establecidas en los artículos $3^{\circ}$ y siguientes de la Ley $\mathrm{N}^{\circ} 20.609$.

Sin embargo, y a pesar de que esta acción legal de carácter especial tiene el loable objeto de proteger derechos de la mayor relevancia, aqueIla, en sí misma, por el hecho de ser una acción que da lugar a un procedimiento judicial, ha de satisfacer el estándar mínimo que los derechos fundamentales exigen de toda actividad estatal (nunca olvidando que los Tribunales son parte del Estado).

Es por ello que, habiendo transcurrido más de cinco años desde el inicio de su vigencia, pareciera de gran relevancia examinar la regulación procesal específica que el legislador ha adoptado para dar vida a esta acción, con el fin de contrastar si aquel es suficiente conforme a la luz de los estándares que exige la tutela judicial efectiva, recordando que este es un derecho fundamental propiamente tal, que no puede ser desconocido ni aún a pretexto de proteger otros derechos constitucionales.

\section{Tutela Judicial Efectiva y Protección de Derechos Fundamentales}

\subsection{De la Protección de los Derechos Fundamentales}

La evolución del pensamiento constitucionalista se ha caracterizado por tener como foco central la "protección de los derechos fundamentales", debido a que ellos son uno de los eslabones principales de la organización social, al punto de que estos, en sí mismos, significan la estruc-

5 De hecho, según el Mensaje de la Ley №20.609, el establecimiento de una acción para reclamar por las discriminaciones arbitrarias busca asegurar la materialización del mandato de no discriminar. 
tura estatal, constituyendo su presupuesto teleológico trascendental. Los derechos fundamentales configuran, de esta forma, el punto principal de interacción entre los individuos y el Estado, siendo la principal garantía de los primeros para con la actividad del segundo, obligando al aparato estatal a dirigir sus fuerzas en tutelar y promover estos derechos. ${ }^{6} \mathrm{De}$ hecho, el pensamiento contractualista nos presenta una sociedad de individuos que, ante la necesidad de proteger sus derechos y libertades inherentes, perfeccionan la organización social para dar vida al Estado Moderno, el cual tendrá como finalidad primordial la consolidación de la protección de los derechos individuales. ${ }^{7}$

Entender que el fin principal de la organización estatal es la protección y promoción de los derechos fundamentales, nos da pie para concebir que el Estado detenta el deber de velar para que los derechos esenciales sean ejercidos sin impedimentos ni limitaciones ilegítimas, permitiendo a sus titulares "echar mano" de ellos para el desarrollo de su propia individualidad. ${ }^{8}$ El Estado debe, por ende, crear las bases para que los derechos fundamentales puedan ser "vividos" por las personas, evitando su reducción a meras declaraciones de principios sin operatividad en la cotidianidad.

Una primera manifestación de este deber estatal se materializaría en

6 Es por ello que se puede afirmar que "[a]sí, se da un estrecho nexo de interdependencia, genético y funcional, entre el Estado de Derecho y los derechos fundamentales, ya que el Estado de Derecho exige e implica para serlo garantizar los derechos fundamentales, mientras que éstos exigen e implican para su realización al Estado de Derecho". Pérez (2004), pp. 19-20. Véase al respecto el interesante trabajo de CANDIA (2017).

7 FIORAVANTI (2000), pp. 39-41. Para este autor, "los individuos confían la protección de sus derechos preestatales a la Constitución, en virtud del ejercicio del poder constituyente que precede a los poderes constituidos, de manera que el imperium que se delega a estos poderes puede ser limitado como garantía y en nombre de la Constitución. Este dualismo entre poder constituyente y poder constituido no sólo entra en crisis cuando el imperium es delegado completa e irrevocablemente a un soberano -como ocurre en el modelo estatalista-, sino también cuando el pueblo rechaza sujetar las manifestaciones de su voluntad a formas y procesos -como ocurre en la degeneración voluntarista-". FIORAVANTI (2000), p. 42.

8 Según los estudios del profesor AldUNATE, este fundamento teleológico del Estado sería un elemento reconocible en las primeras aproximaciones teóricas a la noción de "Estado de Derecho", en las que se le entendía como "una organización existente para permitir a cada individuo su desarrollo individual, y que en esa medida tiene limitados sus fines y tareas, los que deben circunscribirse a garantizar la libertad y la seguridad del individuo, para permitir la persecución, por parte de éste, de sus propios fines (sean temporales o espirituales)". AldDUNATE (2008), pp. 63-65. 
el reconocimiento de ciertos derechos y libertades fundamentales ${ }^{9}$, mediante su recepción en diversas instituciones jurídicas objetivas. El ordenamiento jurídico funcionaría declarando derechos, intereses y bienes jurídicos en normas públicas y vinculantes, que impondrían un deber general de respeto por la sociedad toda, incluyendo inherentemente a los organismos estatales ${ }^{10}$. En otras palabras, el Estado, al reconocer los derechos fundamentales en textos positivos, los dota de una estructura que permite a su titular detentar una expectativa de que aquel no será lesionado, lo que correlativamente se configurará como un deber jurídico atribuible a un otro (a veces singularmente determinado, en otros casos, entendido como el resto de la comunidad). ${ }^{11}$

La idea de una tutela material de los derechos fundamentales responde a la noción de un sistema jurídico destinado a ordenar el comportamiento humano. Sin embargo, es esto mismo lo que hace insuficiente a esta garantía primaria, ya que su satisfacción depende del grado de compromiso que los destinatarios de la norma jurídica tengan hacía con ella, cumpliéndola sin necesidad de una acción coercitiva ${ }^{12}$. GARcía MÁYNEZ nos recuerda que "de que algo sea puede inferirse que algo fue o que algo será, más nunca que otra cosa deba ser. Lo que debe ser puede no haber sido, no ser actualmente y no llegar a ser nunca, perdurando, no

9 "[E]l derecho tiene como una de sus funciones más relevantes la prevención y la composición pacífica de las controversias que puedan surgir entre quienes integran la comunidad social. Dicha función de prevención la acomete el ordenamiento jurídico material al reglamentar y disciplinar la actividad de las personas, al delimitar mediante relaciones jurídicas los vínculos y facultades de los sujetos de derecho". Bordali (2016), p. 166.

10 Una manifestación de aquello lo encontraremos en los incisos primero y segundo del artículo $6^{\circ}$ de la Constitución Política.

11 Para FERRAJOLI, los derechos existen si y sólo si están normativamente establecidos, circunstancia que él denominará como una "garantía primaria" de los derechos fundamentales (idea también conocida como tutela material de los derechos fundamentales), y que explicará siguiendo la noción de derecho subjetivo dada por KELSEN, al afirmar que "[n]o hay derecho subjetivo en relación con una persona (...) sin el correspondiente deber jurídico de otra". FERRAJOLI (2019), pp. 59-63.

12 "[E]l derecho provee seguridad en cuanto previsibilidad, puesto que allí donde rige un ordenamiento jurídico que es en términos generales eficaz, los correspondientes sujetos normativos saben a qué atenerse, es decir, conocen lo que el derecho demanda de ellos y de los demás sujetos y están informados acerca de cuáles serán las consecuencias de los actos que ejecuten en el curso de la vida en sociedad". SQuelLA (2011), p. 714. 
obstante, como algo obligatorio"13, o sea, el hecho de que una norma jurídica exista y reconozca un derecho fundamental no asegura per se que dicha norma será respetada por sus obligados, pues, en la gran mayoría de los casos, dicho "respeto" depende de un mero acto voluntarista del sujeto compelido"14.

Ante la eventualidad del quebrantamiento normativo por parte del propio Estado o del resto de los miembros de la sociedad, se hace necesario un segundo nivel de protección de los derechos fundamentales para que estos tengan una real operatividad. Según HESSE, "la libertad que garantizan los derechos fundamentales no puede entenderse como una esfera del individuo libre de la influencia estatal, que el Estado simplemente haya de respetar. La procura por el Estado de la efectividad de los derechos fundamentales deviene presupuesto de que llegue a haber una real libertad. El Estado ya no aparece sólo como el enemigo potencial de la libertad, sino que tiene que ser también un defensor y protector. Por su parte, es evidente que este papel no está libre de peligros, ya que una ampliación ilimitada de la responsabilidad y actividades del Estado que desemboque en la omnicomprensiva procura, planificación y configuración estatal, anularía toda configuración existencial autorresponsable. (...) Junto a la particularidad de que [las garantías constitucionales] no sólo obligan al Estado a una abstención, sino también a una actuación positiva, plantean la cuestión de si a la obligación jurídico-objetiva del Estado corresponde, y en qué medida, un derecho subjetivo de las personas y los ciudadanos para demandar del Estado tal actuación". ${ }^{15}$

Pero cabe recalcar que este deber de actuar que recae en el Estado podrá tener distintas intensidades y concreciones según lo exija la naturaleza del derecho que se deba materializar o proteger, debiendo reconocerse que todo derecho fundamental para ser tal exigirá del Estado un actuar mínimo que se refleja, a lo menos, en la existencia de un aparato

13 García (2002), p. 9 (las cursivas son nuestras).

14 Entendido aquel, en este caso, como un sujeto pasivo indeterminado, identificado en la comunidad toda. Véase Williams (1999), p. 118. Sobre los destinatarios de los derechos fundamentales, véase Lovera (2017), pp. 165-177.

15 Hesse (2001), p. 95. Véase, además, Gornig (2010), pp. 63-64 y FerRajoli (2016), pp. 55-57. 
público, independiente y eficaz, capaz de reaccionar ante las lesiones cometidas a estos derechos derivadas de la inobservancia a la tutela material o primaria ${ }^{16}$.

Esto es entendido por FERRAJOLI como una garantía secundaria, que emana de la potestad soberana entregada al Estado -la jurisdicción- configurada en mecanismos jurídicos destinados a alcanzar la eficacia de la garantía primaria. ${ }^{17}$ Acá la tutela ya no es meramente un reconocimiento normativo, sino que es una tutela jurisdiccional de los derechos fundamentales ${ }^{18}$, y que puede ser entendida como la existencia de un derecho subjetivo entregado a aquel que ve violado uno de sus derechos fundamentales para acudir al Estado exigiendo la protección jurídica del mismo $^{19}$. La doctrina procesalista ha defendido la existencia de este derecho subjetivo autónomo (distinto del derecho subjetivo que se alega lesionado y que es reconocido por la tutela material ${ }^{20}$, cuyo contenido impulsaría a la actividad jurisdiccional ${ }^{21}$ (por ello se dirá que la jurisdic-

16 Sobre las garantías de los derechos fundamentales, en general, véase NogueIRA (2003), pp. 101-137, así como las interesantes reflexiones de HoLMES y SUNSTEIN (2011), pp. 55-80, respecto de las distintas acciones que el Estado (en especial el Gobierno) debe adoptar para proteger y promover derechos fundamentales.

17 FERRAJOLI (2019), pp. 59-61.

18 Inclusive, hay autores que consideran la existencia de esta tutela -o, mejor dicho, el carácter de "justiciables" de los derechos fundamentales- un presupuesto de existencia del derecho en sí mismo, desconociéndose que "algo" sea "derecho" si no es posible demandar su protección ante Tribunales competentes. Véase, por ejemplo, PEREIRA (2006), pp. 251 y ss.

19 "La segunda [identificación del derecho subjetivo] es la del derecho subjetivo al deber que, en caso de violación, incumbe a un juez aplicar la sanción, es decir, la que he llamado garantía secundaria: El derecho subjetivo consiste no en el presunto interés, sino en la protección jurídica". FERRAJOLI (2019), p. 61.

20 MONTERO, et al. (2018), pp. 208-209.

21 "La pretensión de protección del derecho constituye el acto de amparo judicial que forma el objetivo del proceso. Ella va dirigida al Estado, el cual debe otorgar tal amparo; y se dirige contra la parte contraria, frente a la cual debe ser otorgada dicha protección. Es de naturaleza de derecho público, y no es la emanación del derecho privado subjetivo. (...)". Cita atribuida a Adolf WACH, encontrada en ROMERo (2014a), p. 13. 
ción es un "poder-deber"22 del Estado ${ }^{23}$ ) a dictar una sentencia de fondo ${ }^{24}$ que resuelva un conflicto jurídico.

El derecho subjetivo a la tutela jurisdiccional (o a la tutela judicial, como también es conocido), actualmente es visto como un derecho fundamental en sí mismo ${ }^{25}$, cuyo contenido estaría compuesto por principios, subprincipios y garantías de carácter jurídico, como el acceso a la justicia, la independencia de los Tribunales respecto de los demás poderes del Estado y de las partes del proceso, la obligación de emitir una sentencia sobre el fondo del asunto conforme a derecho, el principio de motivación de las resoluciones judiciales, el principio de proporcionalidad, la prohibición de la indefensión, el efecto de cosa juzgada, la ejecución de lo juzgado, el derecho al recurso, entre otros. ${ }^{26}$ Sin embargo, nuestro análisis se centrará en los tres presupuestos inherentes a la esencia de la tutela judicial: el acceso a la justicia, el debido proceso, y el principio de efectividad ${ }^{27}$.

22 Así define jurisdicción el profesor ColomBo, reconociendo que, por un lado, aquella es un poder, pues su fundamento y fuerza vinculante emana de la soberanía del Estado, pero al mismo tiempo es un deber, ya que el Estado -mediante sus Tribunales- está obligado a actuar cuando es requerida su intervención. Colombo (1991), pp. 41-44. Véase también Bernales (2019), pp. 141-147.

23 Según los estudios del profesor PEREIRA, la jurisdicción sería "aquella facultad abstracta que el Estado delega en los Tribunales para solucionar en forma definitiva y obligatoria los litigios que se susciten entre los particulares [y entre particulares con el Estado] mediante la sentencia, como asimismo para hacer cumplir lo resuelto en ella". Cita encontrada en ColomBo (1991), p. 37. Véase también MONTERo, et al. (2018), p. 65.

24 Se debe reconocer que aún los procesalistas debaten acerca del carácter de dicha sentencia, existiendo autores que defenderán la idea de que el derecho está destinado a alcanzar una sentencia concreta, es decir una sentencia favorable a lo pedido; frente a otros procesalistas que consideran que el derecho sólo está destinado a obtener una sentencia de fondo, sea cual sea el contenido de ella (una sentencia en abstracto). MonTERo, et al. (2005), pp. 245-251.

25 Así lo ha reconocido, por ejemplo, el Tribunal Constitucional chileno. Véase Tribunal Constitucional, Rol N815-07, de 19 de agosto de 2008 , considerandos $9^{\circ}$ y ss.

26 MONTERo, et al. (2005), pp. 251-260.

27 La efectividad de la tutela judicial, a pesar de ser un asunto debatido y controversial en sí mismo, hace relación al acatamiento y cumplimiento de la resolución judicial: que ella sea capaz de producir un cambio en la vida cotidiana de las personas o, en otras palabras, que la jurisdicción logre, realmente, tutelar y reestablecer el derecho inobservado. Así, el principio de efectividad (que se manifiesta, incluso, en el nombre de la tutela judicial, al ser esta "efectiva") se concretará en tres grandes garantías: la inmodificabilidad de las resoluciones judiciales, la potestad cautelar del juez (medidas cautelares), y, especialmente, en la ejecución -incluso compulsivamente- de la resolución judicial firme. PIcó I Junor (2011), pp. 85-97. 


\subsection{Derecho a la Tutela Judicial Efectiva}

Conforme se ha ido explicando hasta este momento, hemos podido reconocer la existencia de un derecho subjetivo, de carácter público, cuyo sentido es permitir a las personas acudir al Estado para solicitarle la protección de un derecho fundamental que se alega lesionado (o amenazado), a efectos de tutelar un estatus jurídico específico que el derecho agraviado entrega a su titular. Sin embargo, los derechos fundamentales -incluyendo el derecho a la tutela judicial- no solo poseen una naturaleza subjetiva, sino que aquellos también pueden ser entendidos objetivamente. En este sentido, los derechos fundamentales son, además, el fundamento sobre los cuales se edificará la sociedad democrática contemporánea, contribuyendo a la conformación e información de todo el orden jurídico de un Estado, como se comentó inicialmente. ${ }^{28}$

Este trasfondo democrático del derecho a la tutela judicial nos demuestra su nivel de importancia: no sólo es un medio de protección frente a las vulneraciones que puedan sufrir las personas en el legítimo ejercicio de sus derechos, sino que su operatividad y eficacia son un presupuesto trascendental para la vida democrática de un país, al punto que puede verse como parte inherente del denominado "umbral mínimo democrático" que toda sociedad sana busca detentar, y gracias al cual podemos entender que la democracia no es sólo un conjunto de procedimientos formales a la luz de los cuales se estructura un Estado, sino que, además, conlleva el cumplimiento de presupuestos materiales básicos, dentro de las que destaca el respeto a las libertades y a los derechos fundamentales de las personas. ${ }^{29}$

Así, la actuación de los Tribunales (del Estado, en definitiva) para proteger los derechos fundamentales dista de ser algo relacionado sólo a los casos concretos, puesto que dicha acción de conocer y resolver los conflictos jurídicos de derechos fundamentales conlleva, a su vez, la consolidación de las bases del Estado democrático de Derecho. De allí emana

28 PéRez (2004), pp. 20-22.

29 CAzOR (2001), pp. 283-284. Véase, además, WALDRON (2005), pp. 337-355. 
la importancia de que el derecho a la tutela judicial no quede sólo en la resolución de un conflicto (o sea, en el simple hecho de que los Tribunales tramiten acciones), sino de que debe avanzar hasta ser una tutela judicial efectiva. ${ }^{30}$

La noción de tutela judicial efectiva hace relación, en palabra de los profesores García PINo y Contreras, al "reconocimiento de un derecho prestacional que recaba del Estado la protección jurídica debida, en el igual ejercicio de los derechos ante la justicia, proscribiendo la autotutela, y garantizando una respuesta a la pretensión de derechos e intereses legítimos con autoridad de cosa juzgada y con la eficacia coactiva que demanda la satisfacción de derechos fundamentales"31. De esta manera, el derecho no es visto sólo como la posibilidad de acudir al Estado (a los Tribunales) ${ }^{32}$, sino que, además, su contenido se relacionaría a un derecho que asegura que el Estado brindará una respuesta, conforme a determinados presupuestos formales y sustantivos, revestida de la posibilidad cierta de concreción en la realidad, mediante la utilización legítima de la coacción en caso de ser necesario. De esa forma, este actuar del Estado no es meramente simbólico o testimonial, sino que está dirigido a generar un cambio en la cotidianidad de las personas, con vocación de tutelar satisfactoriamente los derechos fundamentales cuando aquellos se vean afectados (o amenazados). ${ }^{33}$

$30 \mathrm{El}$ proceso judicial no puede ser un simple método de investigación ni de control social, y mucho menos de opresión popular, sino que debe ser una manifestación del debate pacífico, dialéctico y democrático, representante del último bastión de la libertad de las personas, destinado siempre a un obvio efecto: pacificar a los pueblos al evitar que cada uno se haga justicia por mano propia, o se vea forzado a ver con frustración e impotencia la vulneración de sus derechos más íntimos por aquellos que detenten un poder mayor. Alvarado (2013), pp. 212-214.

31 García y Contreras (2013), p. 244.

32 Que, tal vez, sería una noción más cercana al contenido del derecho fundamental de petición que a la idea de la existencia de un derecho fundamental distinto denominado tutela judicial. De hecho, como observa el profesor CEA, la doctrina procesalista nacional antigua hablaba de un derecho a la acción procesal inspirado directamente en los ancestros positivos del actual artículo 19 N¹4 de la Constitución Política. CEA (2012), p. 433.

33 "[L]a idea de garantía jurisdiccional hace referencia a la protección que se presta a los derechos fundamentales a través del ejercicio de la jurisdicción, es decir, la tutela proporcionada por un funcionario del Estado con carácter imparcial por medio del proceso. En otras palabras, esto dice relación con los diferentes procesos jurisdiccionales que aseguran la vigencia de los derechos frente a su vulneración". PAREDEs (2014), pp. 20-21. 
En Chile, la jurisprudencia constitucional ha reconocido la existencia de este derecho dentro del ordenamiento jurídico interno, a pesar de no existir una consagración expresa en el texto constitucional -ni en normas de rango infraconstitucional- ${ }^{34}$. Ello, pues, el sentido y alcance de las diversas garantías que reconoce -directa e indirectamente- el artículo 19 $N^{\circ} 3$ de la Constitución Política harían obvia la existencia del derecho, al ser la tutela judicial efectiva un presupuesto necesario para la existencia de todas ellas. ${ }^{35}{ }^{36}$

A la mirada jurisprudencial se suman los aportes que el Derecho Internacional de los Derechos Humanos hace al derecho interno en materia de derechos humanos, especialmente mediante Tratados Internacionales. Como ha destacado el profesor NogueIRA, la Corte Interamericana de Derechos Humanos, mediante una interpretación de los artículos $8^{\circ}$ y 25 de la Convención Americana sobre Derechos Humanos, ha reconocido la existencia de una "'obligación a cargo de los Estados de ofrecer, a todas las personas sometidas a su jurisdicción, un recurso judicial efectivo contra actos violatorios de sus derechos fundamentales. (...) En razón de lo anterior, la inexistencia de un recurso efectivo contra las violaciones de los derechos reconocidos por la Convención constituye una trasgresión

34 Aunque debe mencionarse que existiría jurisprudencia del propio Tribunal Constitucional en el cual se defendería la idea de que la Constitución sí reconoce expresamente el derecho a la tutela judicial efectiva o, a lo menos, algunos de sus aspectos trascendentales. Véase, por ejemplo, Tribunal Constitucional, Rol N815-07, de 19 de agosto de 2008, considerando $10^{\circ}$.

35 Esto es coherente con el criterio de interpretación constitucional sistémico-finalista, que entiende que el contenido de las normas que integran el texto constitucional deben ser determinados de manera tal que exista entre ellas la debida correspondencia y armonía, excluyéndose aquella interpretación que conduzca a anular o a privar de eficacia algún precepto de ella (ZAPATA [2008], p. 201). De esta forma, entender que existen manifestaciones de un derecho (en el artículo 19 $\mathrm{N}^{\circ} 3$ ) sin reconocer la existencia del derecho del cual emanan, demostraría una mirada sesgada y restrictiva de la garantía constitucional, ya que transformaría a las instituciones recogidas en el artículo $19 \mathrm{~N}^{\circ} 3$ en "letra inútil", al no existir el presupuesto previo que asegure el acceso a la jurisdicción y el deber del Estado a resolver en el fondo (Tribunal Constitucional, Rol N²92-07, de 3 de enero de 2008 , considerando $7^{\circ}$ ).

36 Tribunal Constitucional, Rol $N^{\circ} 792-07$, de 3 de enero de 2008, considerando $8^{\circ}$. Cabe mencionar que este fallo no habla concretamente de "tutela judicial efectiva" sino que de "derecho a la tutela judicial", y que en resoluciones posteriores del Tribunal (como ocurre en fallo Rol N`8152007), se ha defendido la tesis de que la Constitución reconocería expresamente el derecho a la tutela judicial efectiva. 
de la misma por el Estado Parte'. Hay así un derecho a exigir la tutela judicial efectiva de los derechos ante los órganos competentes, que consiste en la posibilidad efectiva de que toda persona pueda requerir irrestrictamente y obtener la tutela de sus derechos" 37 .

Según ha profundizado el Tribunal Constitucional, "el derecho a la tutela judicial efectiva tiene una doble dimensión, por una parte adjetiva, respecto de los otros derechos e intereses, y por la otra, sustantiva, pues es en sí mismo un derecho fundamental autónomo, que tiene por finalidad que las personas accedan al proceso como medio ordinario de resolución de los conflictos jurídicos, lo que resulta un presupuesto mínimo de todo Estado de derecho"38. Así, la efectividad de la tutela no debe entenderse como un pronunciamiento siempre favorable a las pretensiones del demandante ${ }^{39}$, sino que ésta se concretará en la existencia de un estándar sustantivo -compuesto por diversos valores y principios- alrededor del cual se deben estructurar las vías jurisdiccionales concretas que el Estado pondrá a disposición de las personas para lograr una solución a sus conflictos jurídicos y, con ello, obtener protección a sus derechos cuando ellos -o su ejercicio- se vean amenazados o agraviados ${ }^{40}$.

37 Nogueira (2008), pp. 267-268. La inobservancia de estos postulados, a juicio del profesor NogueIRA, significaría una infracción a los artículos 1.1 y $8^{\circ}$ de la Convención Americana sobre Derechos Humanos.

38 Tribunal Constitucional, Rol №815-07, de 19 de agosto de 2008, considerando $10^{\circ}$ (las cursivas son nuestras).

39 Como ha señalado tradicionalmente el Tribunal Constitucional español, "el artículo 24.1 reconoce el derecho de todos a la jurisdicción, es decir, a promover la actividad jurisdiccional que desemboque en una decisión judicial sobre las pretensiones deducidas, en el bien entendido que esa decisión no tiene por qué ser favorable a las peticiones del actor, y que aunque normalmente recaiga sobre el fondo, puede ocurrir que no entre en él por diversas razones. Entre ellas se encuentra que el órgano judicial instado no se considere competente. Ello supone que el artículo 24.1 no puede interpretarse como un derecho incondicional a la prestación jurisdiccional, sino como un derecho a obtenerla siempre que se ejerza por las vías procesales legalmente establecidas". Tribunal Constitucional de España, Rol №19/1981, de 8 de junio de 1981, considerando $2^{\circ}$. Véase también MARTínez (2012), pp. 133-140.

40 “(...) [L]a tutela judicial se da en el plano de un derecho prestacional ante el Estado a que se responda de las pretensiones de derechos e intereses legítimos que se hacen valer ante la justicia. La respuesta estatal ha de estar revestida de condiciones de autoridad y eficacia que permitan satisfacer los derechos de los interesados en el reclamo judicial". Tribunal Constitucional, Rol N ${ }^{\circ} 2701-14$, de $1^{\circ}$ de septiembre de 2015 , considerando $10^{\circ}$. 
El estándar sustantivo al que se hace mención ${ }^{41}$ tendrá una doble función desde una mirada normativa: una primera, que da cuenta de un deber impuesto al Estado-legislador para que materialice el derecho mediante la instauración de "procedimientos que permitan hacer valer los derechos, los medios de protección que lo cautelen y la perspectiva jurisdiccional cuando sea necesario reivindicarlos en la esfera de la justicia"42. Pero, además habrá una segunda lectura, de carácter limitativa, ya que el deber de instaurar procedimientos judiciales nunca puede ser visto como la entrega de una confianza absoluta al legislador, "quien estaría facultado para determinar con entera discreción los procedimientos judiciales, mismos que, por el solo hecho de ser fijados por el legislador, generarían siempre un procedimiento racional y justo. Esta tesis no ha encontrado jamás apoyo doctrinal o jurisprudencial"43. En otras palabras, el legislador debe desarrollar el derecho, pero no arbitrariamente, sino que conforme al estándar sustancial inherente a la tutela judicial efectiva.

\section{3. “Estándar Sustancial” de la Tutela Judicial Efectiva}

Al no ser materia de este trabajo abordar en profundidad todos los valores y principios que configuran la tutela judicial efectiva ${ }^{44}$, para efecto de este trabajo nos bastará seguir los estudios los estudios del profesor BORDALi45, quien, basándose en la jurisprudencia constitucional, ofrece claridad respecto de cuáles serían los derechos, valores y principios que conforman el mínimo sustancial de la tutela judicial efectiva: ${ }^{46}$

41 Que podemos identificar con el contenido esencial de este derecho, entendiendo por tal aquello que hace que el derecho a la tutela judicial sea tal, y no otra cosa. Ver NogueIRA (2010), pp. 97-99.

42 García y Contreras (2013), p. 240.

43 Tribunal Constitucional, Rol N $792-07$, de 3 de enero de 2008, considerando $7^{\circ}$.

44 Véase, por ejemplo, Nogueira (2007); Navarro (2011); Bordalí (2011); Garcia y Contreras (2013); Bordali (2016); Pacheco y Reyes (2019); o Bernales (2019).

45 Quien, cabe mencionar, no está de acuerdo con la denominación de tutela judicial efectiva, al considerar que el adjetivo "efectiva" es propia de la Constitución española, y que en dicho país ha dado lugar a más de alguna duda interpretativa, por lo que, a su opinión, "no [sería] apropiado importar gratuitamente esos problemas del Derecho Constitucional español a nuestro derecho". BORDALI (2011), p. 315.

46 BoRdalí (2011), pp. 328-334. 
a) El derecho a que un tribunal resuelva las pretensiones conforme a derecho, y a que estas resoluciones, revestidas de fuerza de cosa juzgada, puedan ser ejecutadas compulsivamente en caso de ser necesario, buscando siempre lograr la efectividad de las decisiones emanadas de un juez competente.

b) El derecho de acceso a la justicia. Este derecho ${ }^{47}$, que incluye dentro de su contenido los principios de participar en la sustanciación de un proceso en igualdad de $\operatorname{armas}^{48}$, no es más que un derecho a recurrir ante el Tribunal, como compensación constitucional a la abolición de la autotutela como vía lícita para la solución de los conflictos, obligando al Estado a ser garante del restablecimiento de la vigencia del ordenamiento jurídico cuando aquel se constate inobservado. De esta forma se satisface un interés subjetivo de aquellos en controversia, además de permitir la actuación del derecho objetivo para mantener el cumplimiento de la ley. 49

El estándar exige, por ende, que el legislador fije las acciones que están a disposición de las personas para cuando aquellas estimen necesario acudir a un Tribunal requiriendo la protección de algún derecho, sin fijar más trabas o formalidades que las necesarias -en consideración a la naturaleza especial de su objeto o del derecho que se busque tutelar- ${ }^{50}$. Pero, además, exigirá que el legislador fije armas similares para las partes involucradas en el proceso ${ }^{51}$, a efecto de permitir que todos puedan

47 "(...) [L]a frontera que divide [al derecho a la tutela judicial efectiva del derecho a la acción] se refiere al hecho de que la tutela judicial efectiva garantiza todos los derechos inherentes que permiten acceder a un debido proceso. Por tanto, no trata solamente de si se tiene o no derecho a la acción, sino que abarca las condiciones materiales previas que llevan a una persona a adoptar la decisión de recurrir a un procedimiento legal”. Tribunal Constitucional, Rol N²802-15, de $1^{\circ}$ de septiembre de 2015 , considerando $17^{\circ}$.

48 Bordali (2011), p. 328.

49 Tribunal Constitucional, Rol №205-95, de 31 de enero de 1995, considerando $9^{\circ}$.

50 Evitando, por ejemplo, establecer un solve et repete sin justificación razonable (al respecto, véase LEWIS RIPOLL [2014]). Un estudio sobre las consecuencias que conlleva la inobservancia de esta garantía en materia de acciones judiciales de carácter contencioso-administrativo puede verse en ARósticA (2008), pp. 93-98.

$51 \mathrm{La}$ igualdad procesal no obliga a una identidad exacta entre los involucrados. Podrían entregarse distintas armas según la realidad fáctica de las partes involucradas, siempre que el legislador ofrezca una fundamentación suficiente para concretar normativamente esta distinción 
participar activamente en su sustanciación.

c) El debido proceso. A pesar de que se discute sobre la naturaleza de la relación que existe entre el derecho la tutela judicial efectiva y el debido proceso -e incluso si es que realmente son dos derechos diferentes- ${ }^{52}$, para efectos de este trabajo nos decantaremos por la tendencia que ha seguido la jurisprudencia constitucional nacional, cuando ha expresado que existiría una frontera que separaría a los elementos estructurantes del proceso (la tutela judicial efectiva) de las garantías de racionalidad y justicia internas con las cuales debe desenvolverse el procedimiento judicial (el debido proceso) $)^{53}$.

Al ser el objeto del debido proceso la concreción de un procedimiento judicial conforme a la igualdad y la racionalidad, muchos autores han identificado la garantía con la norma del artículo $19 \mathrm{~N}^{\circ} 3$, inciso sexto, de la Constitución Política ${ }^{54}$, cuando establece que "[t]oda sentencia de un órgano que ejerza jurisdicción debe fundarse en un proceso previo legalmente tramitado. Corresponderá al legislador establecer siempre las garantías de un procedimiento y una investigación racionales y justos".

procesal: “(...) la igualdad ante la ley o en el ejercicio de los derechos no puede consistir en que las partes que confrontan pretensiones en un juicio tengan idénticos derechos procesales. Del momento en que uno es demandante y el otro demandado, tendrán actuaciones distintas; el uno ejercerá acciones y el otro opondrá defensas y excepciones. Cada una de esas actuaciones procesales estará regida por reglas propias, que no pueden ser idénticas, pues las actuaciones reguladas no lo son. (...) [L]a existencia de un trato diferente para una cierta categoría de demandados no es suficiente para concluir que ello es contrario a la Carta Fundamental, pues ésta no prohíbe establecer diferencias, sino que hacerlo arbitrariamente; esto es, careciendo de fundamento razonable que pueda justificarlas". Tribunal Constitucional, Rol N977-07, de 8 de enero de 2008, considerandos $7^{\circ}$ y $9^{\circ}$.

52 Véase García y ContreRas (2013).

53 Tribunal Constitucional, Rol $N^{\circ} 2701-14$, de $1^{\circ}$ de septiembre de 2015 , considerando $10^{\circ}$ : "Por lo tanto, la tutela judicial se da en el plano de un derecho prestacional ante el Estado a que se responda de las pretensiones de derechos e intereses legítimos que se hacen valer ante la justicia. La respuesta estatal ha de estar revestida de condiciones de autoridad y eficacia que permitan satisfacer los derechos de los interesados en el reclamo judicial. Por el contrario, los principios que gobiernan el debido proceso se satisfacen al interior de un procedimiento. En tal sentido, la jurisprudencia de este Tribunal ha sostenido que 'el procedimiento legal debe ser racional y justo. Racional para configurar un proceso lógico y carente de arbitrariedad. Y justo para orientarlo a un sentido que cautele los derechos fundamentales de los participantes de un proceso'".

54 Para un entendimiento sobre el trasfondo de dicha identificación, véase LóPEZ (2006), pp. 189-195. 
Sin embargo, y a pesar de que dicha normativa es relevante para el caso, la noción de debido proceso es mucho más amplia que la idea de un "proceso legalmente tramitado, racional y justo".

Así, pareciera acertado entender el debido proceso como un medio para asegurar, en la mayor medida posible, la solución justa de una controversia ${ }^{55}$ (con independencia de la autoridad que esté llamada a dar dicha solución), para lo cual se contemplarán una serie de garantías procesales -algunas de corte meramente formal, otras más bien sustantivas-, como: “(...) [e]l derecho a un juez predeterminado por la ley ${ }^{56}$, al derecho a un juez o tribunal independiente ${ }^{57}$ e imparcial ${ }^{58}$, al derecho a la defensa jurídica y la asistencia letrada ${ }^{59}$, al derecho a asesoría y defensa jurídica gratuita para las víctimas ${ }^{60}$, al derecho de los imputados a ser asesorados por un defensor público ${ }^{61}$ y a ser asistidos por un traductor o intérprete ${ }^{62}$, al derecho a la bilateralidad de la audiencia ${ }^{63}$, al debido emplazamien-

55 Nogueira (2008), p. 280.

56 "Nadie podrá ser juzgado por comisiones especiales, sino por el tribunal que señalare la ley y que se hallare establecido por ésta con anterioridad a la perpetración del hecho" (artículo 19 №3, inciso quinto, de la Constitución Política).

57 "La facultad de conocer de las causas civiles y criminales, de resolverlas y de hacer ejecutar lo juzgado, pertenece exclusivamente a los tribunales establecidos por la ley. Ni el Presidente de la República ni el Congreso pueden, en caso alguno, ejercer funciones judiciales, avocarse causas pendientes, revisar los fundamentos o contenido de sus resoluciones o hacer revivir procesos fenecidos" (artículo 76, inciso primero, de la Constitución Política). Complementan a este precepto los artículos $8^{\circ}$ del Código Orgánico de Tribunales, y 80 , inciso primero, de la Carta Fundamental.

58 La imparcialidad obliga al juzgador a estar bajo un desinterés objetivo respecto de los hechos y la materia del asunto que debe conocer, así como también bajo un desinterés subjetivo, al no poder tener relación o ser una de las partes involucradas en el conflicto.

59 "Toda persona tiene derecho a defensa jurídica en la forma que la ley señale y ninguna autoridad o individuo podrá impedir, restringir o perturbar la debida intervención del letrado si hubiere sido requerida (...)" (artículo $19 \mathrm{~N}^{\circ} 3$, inciso segundo, de la Constitución Política).

60 "La ley arbitrará los medios para otorgar asesoramiento y defensa jurídica a quienes no puedan procurárselos por sí mismos (...)" (artículo 19 N³, inciso tercero, de la Constitución Política).

61 "Toda persona imputada de delito tiene derecho irrenunciable a ser asistida por un abogado defensor proporcionado por el Estado si no nombrare uno en la oportunidad establecida por la ley" (artículo $19 \mathrm{~N}^{\circ} 3$, inciso cuarto, de la Constitución Política).

62 "(...) Durante el proceso, toda persona tiene derecho, en plena igualdad, a las siguientes garantías mínimas: a) Derecho del inculpado de ser asistido gratuitamente por el traductor o interprete, si no comprende o no habla el idioma del juzgado o tribunal" (artículo 8.2, letra a, de la Convención Americana de Derechos Humanos).

63 “(...) garantía básica tendiente a asegurar que nadie puede ser condenado sin ser oído ni 
to $^{64}$, a la igualdad entre las partes ${ }^{65}$, al derecho de presentar e impugnar pruebas $^{66}$, al principio de congruencia en materia penal ${ }^{67}$ y al derecho de revisión judicial por un tribunal superior ${ }^{68}$, junto a sus problemas jurídicos concomitantes" 69 , a las que, posteriormente, se han ido sumando nuevas garantías, como los principios de proporcionalidad ${ }^{70}$ y de reserva legal en materia procesal ${ }^{71}$, o el derecho a la sentencia motivada ${ }^{72}$.

\section{Examen de la Ley Zamudio bajo la Luz del Derecho a la Tutela Judicial Efectiva}

De acuerdo con lo que hemos explicado en el acápite anterior, el Estado está en la obligación de ofrecer una protección jurisdiccional a las personas, no bastando para ello la implementación legal de una simple

vencido en juicio, o en términos análogos, de que nadie pueda ser condenado sin haber gozado de la oportunidad de ser oído en juicio". ROMERo (2014b), p. 179.

64 "Entre los procesalistas, se sostiene que '[e]n todo caso, lo que nunca puede faltar en algún momento, es el emplazamiento, o sea, la notificación suficiente a los sujetos afectados interesados, de que el proceso existe, que pueden defenderse, y que la sentencia les sea oponible directamente. Durante el curso del proceso, la bilateralidad se manifiesta en el conocimiento que tienen las partes de todos los actos y resoluciones dictadas en el proceso, lo que permite intervenir cada vez que lo estimen necesario"'. GARCíA y ConTRERAS (2013), pp. 265-266.

65 "Este principio consiste en una razonable y equitativa distribución de oportunidad a las partes para hacer valer sus derechos. En palabras de CoUtURE: 'lo que este principio demanda no es una igualdad numérica, sino una razonable igualdad de posibilidades en el ejercicio de la acción y de la defensa'". Orellana (2009), p. 17.

66 "Cabe recalcar la afirmación de Cristián MATURANA respecto de que para que haya una confrontación entre partes, y ésta a su vez tenga sentido, es de gran relevancia que se les otorgue a los sujetos la posibilidad de rendir pruebas para que puedan así acreditar los hechos, o mejor dicho, las afirmaciones que las partes hagan de los hechos". CONGET (2015), p. 201.

67 "La acusación sólo podrá referirse a hechos y personas incluidos en la formalización de la investigación, aunque se efectuare una distinta calificación jurídica" (artículo 259, inciso final, Código Procesal Penal).

68 "(...) Durante el proceso, toda persona tiene derecho, en plena igualdad, a las siguientes garantías mínimas: $h$ ) derecho de recurrir del fallo ante juez o tribunal superior" (artículo 8.2, letra h, Convención Americana de Derechos Humanos).

69 Tribunal Constitucional, Rol N²802-15, de $1^{\circ}$ de septiembre de 2015 , considerando $17^{\circ}$.

70 Interesante es el análisis sobre la relación entre debido proceso y proporcionalidad que consta en el Ilamado "Caso Cascada" (Tribunal Constitucional, Rol N²922-2015, de 29 de septiembre de 2016).

71 "Los órganos del Estado actúan válidamente previa investidura regular de sus integrantes, dentro de su competencia y en la forma que prescriba la ley" (artículo $7^{\circ}$, inciso primero, Constitución Política).

72 Tribunal Constitucional, Rol N³008-16, de 27 de diciembre de 2016, considerandos $5^{\circ}$ y $6^{\circ}$. 
acción judicial, sino que debe instaurar toda una maquinaria estatal (orgánica y procesal) dirigida a lograr la tutela efectiva de los derechos (una tutela intencionada) que responda sobre el fondo del asunto. Para ello, el Estado debe regular una serie de procedimientos judiciales en cuyo "ADN" ha de constar el respeto al "estándar sustancial" de la tutela judicial efectiva, puesto que no es lícito vulnerar este derecho ni aún bajo el pretexto de proteger con ello otros derechos fundamentales: la protección Estatal tiene que buscar la coherencia del sistema.

Con la Ley $\mathrm{N}^{\circ} 20.609$, el legislador creó una acción jurisdiccional especial cuyo objeto es combatir la "discriminación arbitraria"73 (concordante al tenor del artículo $19 \mathrm{~N}^{\circ} 2$, inciso segundo, de la Constitución $)^{74}$. Esto pues, como señala la profesora RosALEs, "[q]uienes impulsaron el proyecto [de ley antidiscriminación] sostuvieron una crítica evaluación del recurso de protección, siendo este el fundamento principal para afirmar la necesidad e importancia de consagrar un mecanismo procesal idóneo y

73 Cabe señalar, eso sí, que la propia ley define el concepto de discriminación arbitraria y, por ende, al deducirse la acción de no discriminación arbitraria será a aquel concepto al cual habrá que atenerse. Según el artículo $2^{\circ}$ de la Ley, se entiende por discriminación arbitraria: "toda distinción, exclusión o restricción que carezca de justificación razonable, efectuada por agentes del Estado o particulares, y que cause privación, perturbación o amenaza en el ejercicio legítimo de los derechos fundamentales establecidos en la Constitución Política de la República o en los tratados internacionales sobre derechos humanos ratificados por Chile y que se encuentren vigentes, en particular cuando se funden en motivos tales como la raza o etnia, la nacionalidad, la situación socioeconómica, el idioma, la ideología u opinión política, la religión o creencia, la sindicación o participación en organizaciones gremiales o la falta de ellas, el sexo, la maternidad, la lactancia materna, el amamantamiento, la orientación sexual, la identidad de género, el estado civil, la edad, la filiación, la apariencia personal y la enfermedad o discapacidad.

(...) Se considerarán razonables las distinciones, exclusiones o restricciones que, no obstante fundarse en alguno de los criterios mencionados en el inciso primero, se encuentren justificadas en el ejercicio legítimo de otro derecho fundamental, en especial los referidos en los números $4^{\circ}$, $6^{\circ}, 11^{\circ}, 12^{\circ}, 15^{\circ}, 16^{\circ}$ y $21^{\circ} \mathrm{del}$ artículo 19 de la Constitución Política de la República, o en otra causa constitucionalmente legítima". Sobre una visión crítica respecto de la calidad de esta definición, véase DíAz (2019), pp. 267-270.

74 Este sentido es destacado por la profesora Vivanco: "En este contexto, el principio de igualdad se manifiesta como una protección ante el ordenamiento jurídico y ante la autoridad, para que una persona no se vea afectada por diferencias irracionales. Ello no implica, como ya se señaló, un tratamiento igual para todos los casos, con abstracción de cualquier elemento diferenciador de relevancia jurídica; así como tampoco se prohíbe un trato distinto ante situaciones razonablemente desiguales. Lo que sí se sanciona y prohíbe es el establecimiento de distinciones manifiestamente irracionales y arbitrarias". VIVANCO (2006), p. 340. En similar sentido, Tribunal Constitucional, Rol N811-07, de 31 de enero de 2008, considerando $18^{\circ}$. 
especial que permita repudiar toda conducta contraria a la no discriminación. A juicio de este sector, los estudios referenciados permitían concluir que la acción consagrada en la Constitución no habría sido eficiente para la protección de este derecho"75. Es justamente por ello que el artículo $1^{\circ}$ de la Ley $\mathrm{N}^{\circ} 20.609$ sincera sus intenciones en materia de tutela judicial: "Esta ley tiene por objetivo fundamental instaurar un mecanismo judicial que permita restablecer eficazmente el imperio del derecho toda vez que se cometa un acto de discriminación arbitraria".

\subsection{Finalidad de la Acción de No Discriminación Arbitraria y Efectividad de la Decisión Jurisdiccional}

El artículo $3^{\circ}$ de la Ley $\mathrm{N}^{\circ} 20.609$ señala que "[I]os directamente afectados por una acción u omisión que importe discriminación arbitraria podrán interponer la acción de no discriminación arbitraria, a su elección, ante el juez de letras de su domicilio o ante el del domicilio del responsable de dicha acción u omisión". De esta forma, la acción "busca determinar si ha existido o no una discriminación arbitraria, y en caso afirmativo, ordenar se deje sin efecto el acto discriminatorio y disponer, ya sea su no reiteración, o bien que se realice el acto omitido"76.

Claramente la acción está dirigida a lograr un cambio en la realidad, repudiando las conductas atentatorias al derecho fundamental, por ello, la acción se centra en proteger un derecho individual de forma semejante a lo que ocurre con la acción de protección. De hecho, según el artículo 12 de la Ley $\mathrm{N}^{\circ} 20.609$, el juez contará con el poder suficiente para adoptar todas las providencias y medidas que estime necesarias para restablecer el imperio del derecho y asegurar la debida protección del afectado; potestades muy similares a las que entrega el artículo 20 del texto constitucional al juez ("[...] la que adoptará de inmediato las providencias que juzgue necesarias para restablecer el imperio del derecho y asegurar la debida protección del afectado").

De esta manera, y siguiendo la lógica del profesor Soto KLoss respec-

75 Rosales (2014), p. 257.

76 CASAS y Lagos (2014), p. 128. 
to de la naturaleza del recurso de protección, la acción de no discriminación podría verse, también, como una materialización de las facultades conservadoras (superintendencia directiva) de las que están dotados los Tribunales de Justicia, conforme lo reconoce el artículo $3^{\circ}$ del Código Orgánico de Tribunales, que implican el ejercicio pleno de la jurisdicción (de la soberanía nacional) para conocer del asunto y, en caso de constatar la lesión al derecho fundamental, imponer toda medida de protección ("providencias que se estimen necesarias") mediante mandatos revestidos de imperio contra el ofensor a efectos de lograr la conservación de la situación jurídica existente antes del acto u omisión antijurídica. ${ }^{77}$ Todo lo dicho demuestra que no basta con que el juez decrete la existencia de un acto $u$ omisión arbitrariamente discriminatoria, sino que debe actuar para proteger efectivamente el derecho a no ser discriminado ${ }^{78}$.

Este sentido de la acción, que centra todo su poder en proteger el derecho, daría una explicación sobre el por qué aquella no contempla como mecanismo de reparación del daño provocado por una conducta discriminatoria, la posibilidad de demandar una indemnización de per-

77 Sото (1982), pp. 246-247. Véase, además, LetuRIA (2018), pp. 230-231. Cabe mencionar que es interesante la reflexión que se plantea al concepto de "facultades conservadoras" en PAREDES (2014), pp. 21-26.

78 Lamentablemente, son pocos los fallos en que los Tribunales han adoptado medidas significativas para el restablecimiento del imperio del derecho, apreciándose una "timidez" por parte de los jueces para utilizar las potestades que les entrega la ley, siendo común aquel tipo de sentencia que se limita a declarar la existencia de una discriminación arbitraria que debe dejarse sin efecto para, consecuencialmente, condenar a una multa a beneficio fiscal.

Tal vez los ejemplos más destacables en los que un juez ha ejercido efectivamente estas potestades se ven en Juzgado de Letras en lo Civil $\left(2^{\circ}\right)$ de La Serena, Rol N ${ }^{\circ} \mathrm{C}-2903-2015$, de 14 de septiembre de 2016 (en donde el Tribunal ordenó "a Sociedad [P.L.S.], a construir un elevador o ascensor en la pasarela construida sobre avenida Huanhualí, entre avenida El Santo y Alberto Solari, ajustado a la normativa y estándares vigentes acerca de la accesibilidad universal, que sea funcional en todo horario, en un plazo de 120 días, y a la I. Municipalidad de La Serena, a dar estricta aplicación para la referida construcción, al artículo 3 letra e) y artículo 24 letras a) de la Ley 18.695 Orgánica Constitucional de Municipalidades, en armonía con la Convención de Derechos con Personas con Discapacidad y su protocolo facultativo", aunque posteriormente este fallo fue revocado por la Corte Suprema), y en Juzgado de Letras en lo Civil ( $4^{\circ}$ ) de Antofagasta, Rol NC-5451-2013, de 30 de junio de 2014 (mediante la que "se ordena a la Secretaría Regional Ministerial de Obras Públicas de la Región de Antofagasta, que instruya un sumario administrativo a fin de determinar la participación y responsabilidades funcionarias, que pudieran concurrir en el acto discriminatorio determinado en esta sentencia, dentro de tercero día contado desde que la presente sentencia cause ejecutoriada"). 
juicio, aspecto que se ha convertido en una de las principales críticas formuladas contra la regulación de esta acción. Aunque, también existen antecedentes que dan a entender que la verdadera razón por la cual no se permitió la posibilidad de dar lugar a una indemnización de perjuicio contra el victimario deriva a la naturaleza del proceso ${ }^{79}$.

Sin perjuicio de cual sea la razón de ello, esta crítica relacionada a la imposibilidad de demandadar indemnizaciones de perjuicio se profundiza si se observan las características especiales que revisten las causas de derecho antidiscriminatorio. Un caso ejemplificador de esto es "Jiménez con González", en donde el padre de una menor con un alto grado de discapacidad física denunció los malos tratos que ella habría sufrido por parte de una persona que le reprochó, violentamente, el uso indebido de un estacionamiento reservado para personas con alguna discapacidad. Frente a esta denuncia, el Tribunal consideró declarar inadmisible la acción, debido a que los actos sufridos por la hija del actor, "pese a ser ofensivos y basarse en una característica o situación de aquellas consideradas como categorías sospechosas de discriminación, no dan lugar a la acción intentada, por no conllevar una decisión susceptible de revocar, sin perjuicio de la acción penal que tiene el afectado por el delito de injurias, lesiones o amenazas que puede constituir, y demás acciones en el orden educativo que le competan", esto pues "las finalidades de la acción contemplada en la Ley $N^{\circ} 20.609$, se desprende que el acto u omisión que importen discriminación arbitraria, deben ser constitutivos de una decisión, provocar un efecto que pueda ser revertido por el Tribunal al catalogarlo de discriminatorio y arbitrario en los términos de la ley citada,

79 Como recoge la profesora Rosales, "la Comisión de Derechos Humanos [del Senado recomendó] no incorporar una norma especial sobre indemnización por estimar que se requiere un procedimiento diferente en el que pueda discutirse la existencia de los elementos que harian procedente la indemnización de perjuicios, por lo mismo se optó por dejar esta materia a la regulación de las normas generales" (Rosales [2014], p. 277).

En fallo Juzgado de Letras en lo Civil $\left(22^{\circ}\right)$ de Santiago, Rol N ${ }^{\circ} \mathrm{C}-20750-2012$, de 25 de junio de 2013, el Tribunal señaló: "Es absolutamente clara la ley en señalar que las posibilidades que tiene la judicatura, en relación al artículo 12 de la misma, se encuentran totalmente acotadas, y más aún, en el orden patrimonial, limitadas a la interposición de una multa a beneficio fiscal, con lo que se evita la proliferación de éste tipo de juicios con fines meramente lucrativos o especulativos" (considerando $22^{\circ}$ ). 
no basta con que el acto involucre una categoría de aquellas mencionadas en la ley, como es en el caso, y una conducta deleznable, ofensiva y grave. Es necesario que junto con la categoría y conducta vaya aparejado una distinción, exclusión o restricción que genera un efecto que mediante la acción se pretende dejar sin valor. Luego, accesoriamente el acto declarado discriminatorio tendrá como consecuencia para su autor, una multa"80.

A pesar de lo criticable que es esta decisión, el caso nos permite comprobar las características especiales de los hechos que se discuten en la sustanciación de la acción de no discriminación arbitraria, en donde los actos discriminatorios tienden a ser imposibles de revocar, pues en variadas oportunidades se manifiestan como actos de violencia, insultos, malos tratos, o desconsideraciones, que hacen lógico comprender que la simple declaración de la discriminación arbitraria pareciera ser insuficiente para proteger el derecho e inhibir futuras vulneraciones.

La Ley responde a esta preocupación mediante el inciso segundo de su artículo 12, que señala que "[s]i hubiere existido discriminación arbitraria, el tribunal aplicará, además, una multa de cinco a cincuenta unidades tributarias mensuales, a beneficio fiscal, a las personas directamente responsables del acto u omisión discriminatorio". Sin embargo, es de mi parecer que la multa tampoco logra tener un efecto relevante en este sentido, debido a que no incentiva a los afectados a accionar en búsqueda de protección, ni tiene un efecto preventivo o disuasorio de la comisión de futuros atentados ${ }^{81}$, sumado a que los jueces rara vez usan esta herramienta procesal (que, según el tenor del artículo, debiera ser de aplicación forzosa para el juez) ${ }^{82}$.

Se debe considerar que, desde los primeros años de vigencia de la

80 Juzgado de Letras en lo Civil de Ancud, Rol N C-210-2015, de 25 de mayo de 2015, considerandos $3^{\circ}$ y $4^{\circ}$.

81 Crítica que es más profunda cuando el condenado es el propio Fisco, pues, como señala el profesor DíAz: "Un punto que ha sido objeto de controversia es la pertinencia de aplicar la sanción antes señalada a organismos públicos. Como se trata de una multa a beneficio fiscal, para algunos no tendría sentido imponerla, ya que el dinero saldría de las arcas fiscales para entrar a las mismas arcas fiscales". DíAz (2017), p. 473.

82 Véase las interesantes estadísticas al respecto en DíAz (2018), pp. 26-27. 
Ley $\mathrm{N}^{\circ} 20.609$, se hizo notar que la ausencia de sanciones efectivas y reparaciones oportunas daría muy poca utilidad a la acción, ya que la imposibilidad de reclamar la indemnización "[desalienta] a los afectados, interesados no solamente en impugnar el acto discriminatorio, sino obtener el resarcimiento de los daños y perjuicios que éste pueda haberles ocasionado"83. En opinión del profesor MuÑOz, en el contexto antidiscriminatorio la reparación juega un rol importantísimo, ya que la experiencia de ser víctima de una situación discriminatoria es socialmente denigrante, y transmite el mensaje de que el ofendido tiene un estatus inferior, causando un perjuicio a la autoestima de la víctima. Esta reparación puede configurarse en símbolos (como pedir disculpas públicas) y/o en indemnizaciones, cuya importancia radicará en que no sólo busca sancionar al autor, sino que también demuestra una desaprobación social a la discriminación mediante herramientas que buscan compensar a quien se le impuso un sufrimiento ilegítimo ${ }^{84}$.

El ordenamiento jurídico nacional reconoce fórmulas alternativas que permiten dar una mayor efectividad a acciones judiciales que se podrían replicar en el procedimiento antidiscriminatorio. Un ejemplo de ello es el método utilizado por la Ley sobre $\mathrm{V}_{\mathrm{IH}} 85$, que, en su artículo $8^{\circ}$, sanciona las inobservancias al deber confidencialidad y de notificación oportuna de los resultados del examen de detección del virus ${ }^{86}$, mediante la aplicación de multas a beneficio fiscal, "sin perjuicio de la obligación de responder de los daños patrimoniales y morales causados al afectado, los que serán apreciados prudencialmente por el juez"87.

83 Rodríguez (2013), p. 119. "[T]odos estos beneficios especiales son repudiados por nuestro legislador, fundado en el temor a sufrir el aumento considerable de los litigios como consecuencia de la transformación de los pleitos en fuentes de lucro personal. Efectivamente el legislador manifestó su aprehensión en ese sentido y, lejos de allanar el camino a la víctima para perseguir la responsabilidad, estatuyó un proceso de lato conocimiento que, paradójicamente resultaba mucho más idóneo para resolver la procedencia del derecho a la indemnización". ROSALES RIGOL (2014), p. 278.

84 MuÑOZ (2015), pp. 25-26.

85 Ley $N^{\circ} 19.779$ (2001).

86 Artículo $5^{\circ}$ de la Ley $N^{\circ} 19.779$.

87 Un ejemplo sobre la forma en que ha operado dicha regla en la práctica jurisprudencial puede apreciarse en Juzgado de Letras en lo Civil $\left(12^{\circ}\right)$ de Santiago, Rol $N^{\circ} \mathrm{C}-6743-2010$, de 24 de 
Otra alternativa es dotar a la resolución que declara la existencia de una discriminación arbitraria de un efecto similar al entregado por los artículos 178 y 180 del Código de Procedimiento Civil a la sentencia penal, haciendo innecesario volver a discutir los hechos o la responsabilidad, para que, en caso de que la víctima así lo quiera, éste "preparada" la vía para la apertura de un juicio posterior -tramitado acorde a las reglas del juicio sumario-, en donde se discuta únicamente sobre la especie y montos de los perjuicios que se han sufrido. ${ }^{88}$

\subsection{Acción de No Discriminación Arbitraria y el Acceso a la Jurisdicción}

\section{La esencia del acceso a la jurisdicción es que las personas puedan}

enero de 2012, donde se resolvió: “(...) Que, sin perjuicio de lo sostenido con antelación, la norma contenida en el artículo $8^{\circ}$ de la Ley 19.779, faculta al Tribunal para apreciar prudencialmente el daño moral. Que, en este punto, cabe señalar que la circunstancia de que la sociedad [M.] hubiere faltado a la imposición legal de cumplir cabalmente el procedimiento para la detección del Virus de Inmuno Deficiencia Humana, evidentemente constituye una infracción que acarrea perjuicios al paciente, dado que la inestabilidad e incertidumbre de ser portador, y con ello potencial transmisor del citado virus, provoca aflicción en el afectado e impide que se ejecuten los tratamientos necesarios e indispensables para aminorar sus efectos y evitar su propagación, o se ejecutan tratamientos que exceden el ámbito de necesarios y pertinentes, con el consecuencial gasto patrimonial, de modo que, al amparo de dicha disposición legal, como asimismo teniendo en consideración que los antecedentes del proceso se estiman suficientes para sustentar una presunción grave, precisa y concordante con lo sostenido con antelación, en los términos que exige el artículo 1712 del Código de Procedimiento Civil [sic], se fijará prudencialmente como monto de la indemnización por concepto de daño moral que el demandado deberá pagar a favor del actor (...)" (considerando $24^{\circ}$ ).

88 Inspirándonos, claramente, en la lógica procedimental recogida en el inciso segundo del artículo 173 del Código de Procedimiento Civil. De similar opinión es el profesor RodRíguez, quien, apreciando que el procedimiento ya contiene fases de discusión y de prueba en las que se resuelve gran parte de los supuestos necesarios para una acción de indemnización de perjuicios, no vería la razón para que los perjuicios debieran ser demandados posteriormente mediante un nuevo juicio de lato conocimiento, que signifique volver a discutir los supuestos resueltos. RodRiGUEZ (2013), pp. 198-199.

Cabe mencionar que una estructura similar era reconocida en la propuesta legislativa original, cuyo artículo $6^{\circ}$ contemplaba la siguiente fórmula: "Asimismo, la Corte podrá declarar la procedencia de indemnizaciones, que en su caso correspondan, para reparar el daño moral y material ocasionado. En dicho caso, el afectado podrá demandar ante el juez de letras competente, la determinación de la indemnización de los perjuicios que procedieren. El monto de la indemnización será determinado en procedimiento breve y sumario". Lamentablemente, esta redacción sería descartada durante la tramitación del proyecto de ley (Discusión en Sala de fecha 21 de junio de 2005, Cámara de Diputados, Historia de la Ley №20.609, pp. 51 y siguientes). 
acudir ante un Tribunal, sin mayores trabas formales que las razonablemente necesarias, coherentes con la naturaleza del bien jurídico que la acción en cuestión busca tutelar. De esta manera, el legislador pensó en un procedimiento "más o menos" desformalizado, sin perjuicio de que el artículo 14 de la Ley plantea una regla de supletoriedad ante los vacíos procesales que nos permite traer al caso gran parte de las normas del Código de Procedimiento Civil (que es muy formalizado). De esto emanan ciertos aspectos que debemos comentar.

Una primera observación se centra en el artículo $4^{\circ}$ de la Ley ${ }^{89}$ que aborda la legitimación activa requerida para el ejercicio de la acción. La regla pareciera ser bastante flexible, sin embargo, en la práctica ha actuado restrictivamente, pues al exigir la participación -directa, indirecta o ratificatoriamente- de aquel que ha visto lesionado su derecho (la víctima), se ve mermado el sentido "protector" y "desformalizado" que se esperaría de la acción antidiscriminatoria, puesto que con ello la Ley excluye toda posibilidad de que una agrupación (por ejemplo, un órgano estatal o asociaciones privadas como Fundación "Descúbreme" o el MOVILH90) pueda accionar frente a actos de discriminación que sufran sus miembros o simpatizantes. Como bien ha observado el profesor DíAZ DE VALDÉS, este precepto es coherente con una mirada individualista del fe-

89 Artículo $4^{\circ}$ de la Ley N²0.609: "La acción podrá interponerse por cualquier persona lesionada en su derecho a no ser objeto de discriminación arbitraria, por su representante legal o por quien tenga de hecho el cuidado personal o la educación del afectado, circunstancia esta última que deberá señalarse en la presentación.

También podrá interponerse por cualquier persona a favor de quien ha sido objeto de discriminación arbitraria, cuando este último se encuentre imposibilitado de ejercerla y carezca de representantes legales o personas que lo tengan bajo su cuidado o educación, o cuando, aun teniéndolos, éstos se encuentren también impedidos de deducirla".

90 Véase Juzgado de Letras en lo Civil $\left(4^{\circ}\right)$ de Santiago, Rol N ${ }^{\circ} \mathrm{C}-31281-2016$, de 25 de enero de 2017, donde el Tribunal resolvió: "Que, en los hechos relatados y fundantes de la presente acción, éstos no han sido dirigidos contra de la Señora [B.H.] ni atentan en contra de sus derechos fundamentales, en forma directa y específica, (como lo dispone la ley citada), sino que conforme a sus propios relatos, estos atentarían en contra del género femenino y la ley conforme se ha expuesto latamente, tiende a proteger los derechos individuales de los directamente afectados con un acto discriminatorio" (considerando $8^{\circ}$ ). También es interesante Juzgado de Letras en lo Civil $\left(2^{\circ}\right)$ de Valparaíso, Rol $N^{\circ} \mathrm{C}-304-2016$, de 20 de octubre de 2017, donde el Juez estimó que la acción deducida por un grupo de parlamentarios debía declararse inadmisible por no ser ellos los directamente afectados por la arbitrariedad denunciada. 
nómeno discriminatorio, que daría cuenta de una timidez del legislador para abordar los temas profundos del derecho antidiscriminatorio91.

A lo dicho ha de sumarse la exigencia de que el actor cuente con patrocinio de abogado para deducir su acción. A pesar de que la norma no lo explicita, así se ha desprendido de la aplicación supletoria de las normas procesales civiles $^{92}$.

Sin perjuicio de que este aspecto también podría ser discutido en virtud a los aires desformalizadores del procedimiento ${ }^{93}$, el punto al cual se ha de centrar nuestra crítica estaría en la igualdad de cargas que las partes deben soportar en el proceso (en este caso, para actuar válidamente en el procedimiento), ya que, en relación al demandado, la Ley sólo establece en su artículo $8^{\circ}$, un deber (mejor dicho, una carga procesal) de informar al Tribunal (nomenclatura similar a la utilizada en el Auto Acordado sobre Tramitación del Recurso de Protección). Esto, per se no es algo indeseado, e incluso, como bien se sabe, una misma lógica es usada en la acción de protección, donde el denunciado no está obligado a informar bajo el patrocinio de abogado, lo cual es lógico conforme al sentido de tramitación especial y sumarísima que se insta dar al procedimiento; sin embargo, dicha celeridad (que compartiría también la acción en comento) es menor en el procedimiento de la Ley Zamudio, al contemplar un mayor número de trámites formales, como son la fase de conciliación, términos probatorios y audiencias. Pero, lo que sí afectará la igualdad de cargas será, justamente, que el demandante requerirá contar

91 DiAz (2013), pp. 290-291.

92 "Que de la simple lectura del expediente de autos, constatándose la forma de acompañar la prueba, la rendición de la testimonial sólo con la presencia de la parte denunciada que la ofreció, la inclusión de ciertos hechos intrascendentes para el objeto del juicio, es de fácil comprobación que en los procedimientos iniciados en el contexto de la Ley 20.609 se debería contar con la asistencia de un letrado, para evitar equivocaciones procesales, o a mayor abundamiento, reiteración de pruebas, o presentación de antecedentes totalmente irrelevantes para la resolución de las pretensiones de las partes (...). [A]sí la circunstancia que las partes concurran sin ser representadas, puede ocasionar que las actuaciones procesales no se ajusten a los procedimientos establecidos por los códigos respectivos y desconocer la técnica jurídica, lo que puede dar la posibilidad a socavar las pretensiones de quienes la invocan". Juzgado de Letras en lo Civil $\left(22^{\circ}\right)$ de Santiago, Rol N ${ }^{\circ} \mathrm{C}-20750-2012$, de 25 de junio de 2013, considerando $4^{\circ}$.

93 MuÑOz (2015), p. 25. 
con abogado para presentar su demanda, mientras el demandado no lo necesitará para presentar su informe.

Estimamos que una mirada igualitaria de las exigencias de participación en el proceso exigiría una mayor atención sobre los puntos comentados, ya sea permitiendo una participación del demandante sin necesidad de patrocinio de abogado (opción que no adherimos), que ambas partes deban actuar con patrocinio, o establecer una multa contra el demandado que no informe cuando ha sido debidamente emplazado (tal como establece el numeral $15^{\circ}$ del Auto Acordado sobre Tramitación del Recurso de Protección).

Ahora bien, mirando la regulación sobre la legitimación pasiva, es muy destacable que la acción pueda interponerse contra los actos de autoridad, así como también contra actos de privados, demostrando una amplitud necesaria para la determinación del sujeto demandado. ${ }^{94}$

\subsection{Estándar del Debido Proceso en el Procedimiento} Antidiscriminatorio

Ahora bien, la relación entre la acción antidiscriminatoria y el debido proceso nos da pie para los siguientes comentarios:

a) Respecto de la garantía del juez predeterminado por ley, no cabe la duda de que la normativa pareciera clara: es competente el juez de letras en lo civil del domicilio de la víctima o del ofensor, a decisión del demandante.

En este aspecto es poco lo que se puede comentar, salvo recordar la crítica que parte de la doctrina ha formulado contra el legislador respecto a su elección ${ }^{95}$. Sin embargo, no puede afirmarse que no se satisface

\footnotetext{
94 Aunque hay sentencias excepcionales que miran los presupuestos de la legitimación pasiva desde una perspectiva más restrictiva, exigiendo, por ejemplo, que el demando tenga personalidad jurídica, como ocurrió en los casos Juzgado de Letras y Familia de Lautaro, Rol $\mathrm{N}^{\circ} \mathrm{C}-145-$ 2015, de 29 de febrero de 2016, y Juzgado de Letras en lo Civil $\left(1^{\circ}\right)$ de Valdivia, Rol $\mathrm{N}^{\circ} \mathrm{C}-1509$ 2015, de 21 de agosto de 2015.

95 Ya que el legislador optó por entregar esta competencia al juez civil y no a las Cortes de Apelaciones, las que detentarían una mayor experiencia conociendo acciones de naturaleza similar. Para un desarrollo de ésta crítica, véase Rosales (2014), p. 260. Cabe señalar que, tal vez, la principal razón de esta decisión del legislador fue buscar ampliar la cobertura del acceso a la jus-
} 
la garantía en cuestión. Aunque, cabe reconocerse que, en materia de reglas de competencia absoluta, existió algún grado de confusión durante los primeros años de vida de la acción, especialmente respecto de la determinación del tribunal competente cuando el denunciado cuenta con fuero (debate que se centra en saber qué Ley aplicar conforme al criterio de la especialidad). La tendencia jurisprudencial se ha decantado por respetar las reglas comunes del Código Orgánico de Tribunales para resolver estos dilemas, por entender aquellas normas como de orden público ${ }^{96}$.

b) En relación con los derechos al juez independiente y al juez imparcial, tampoco habría mayor reproche que hacer, ya que los diversos organismos que serán competentes para conocer de la acción en sus distintas instancias serán integrantes del Poder Judicial (Juzgados de Letra en lo Civil y Cortes de Apelaciones), siendo plenamente aplicables las normas del Código Orgánico de Tribunales (especialmente sus artículos $1^{\circ}, 12$ y aquellos respectivos a las implicancias y recusaciones). Lo mismo ocurre sobre las garantías de bilateralidad de audiencia (que se manifiesta, entre otras formas, con la posibilidad de que el demandado informe) y debido emplazamiento, en las que se aplicarán supletoriamente las reglas del Código de Procedimiento Civil (artículos 38 y siguientes).

c) Algo similar a lo dicho en la letra anterior puede replicarse respecto de la garantía a la defensa jurídica y a la asistencia letrada gratuita, ya que no se vislumbran argumentos para no hacer aplicables las reglas sobre asistencia gratuita de carácter general97 (además, sobre la necesidad

ticia, existiendo así un órgano jurisdiccional competente en la mayoría de las comunas del país.

96 " $5^{\circ}$ ) Que si bien es cierto la Ley 20.609 regula un procedimiento especial en atención a una determinada materia; no lo es menos, que las normas sobre competencia son de orden público, $y$ en este sentido, existiendo un tribunal especial que deba conocer de determinados asuntos, son estos los que prevalecen por sobre los tribunales ordinarios. $6^{\circ}$ ) Que por otro lado, el fuero como una de las reglas que determinan la competencia absoluta, está establecido precisamente en favor de aquellas personas que no poseen ninguna investidura especial, y no en favor de los que la detentan, como erróneamente lo considera la parte demandante". Juzgado de Letras en lo Civil $\left(1^{\circ}\right)$ de Santiago, Rol N ${ }^{\circ} \mathrm{C}-9118-2014$, de 17 de septiembre de 2014 , considerandos $5^{\circ}$ a $6^{\circ}$.

97 De hecho, son varios los casos en los que la Corporación de Asistencia Judicial ha ejercido patrocinio de denunciantes con escasos recursos. Ejemplo de esto son los casos Juzgado de Letras en lo Civil $\left(29^{\circ}\right)$ de Santiago, Rol N C-20679-2016, de 13 de marzo de 2017; Juzgado de 
de contar con patrocinio de abogado para demandar ya se han hecho observaciones anteriormente). ${ }^{98}$

d) Sobre el derecho a contar con auxilio de intérprete, la Ley no explicita ningún tipo de regla al respecto, pero sí considera al "idioma" como uno de aquellos motivos ejemplificadores de discriminación arbitraria (artículo $2^{\circ}$ ). Ahora, sobre el asunto, gracias a la remisión del artículo 14 de la Ley $\mathrm{N}^{\circ} 20.609$, será plenamente aplicable al procedimiento la regla del artículo 63 del Código de Procedimiento Civil.

e) En materia probatoria, la jurisprudencia referida a la acción de no discriminación arbitraria ha demostrado la existencia de grandes problemas procesales ${ }^{99}$, sin embargo centraremos nuestra atención en aquellos referidos a la carga probatoria.

Debido a que no existe una regla especial sobre la carga de la prueba en la Ley $N^{\circ} 20.609$ (ya que su artículo 10 se refiere sólo a la valoración), licito es debatir sobre cuál de las partes (o, mejor dicho, en qué grado cada parte) tendrá la necesidad de aportar los medios de prueba necesarios para acreditar/desacreditar los presupuestos fácticos que serán objeto del proceso, o, mejor dicho, cuál de las partes deberá soportar las consecuencias negativas por la insuficiencia probatoria ${ }^{100}$.

Letras en lo Civil $\left(1^{\circ}\right)$ de Puente Alto, Rol N ${ }^{\circ} \mathrm{C}-3388-2015$, de 26 de agosto de 2016; o Juzgado de Letras en lo Civil de Constitución, Rol N C-41-2013, de 23 de abril de 2014.

98 No vemos razón para que los casos en que el demandado sea la Corporación de Asistencia Judicial (como ocurrió en Juzgado de Letras en lo Civil $\left(19^{\circ}\right)$ de Santiago, Rol N ${ }^{\circ} \mathrm{C}-25799-2015$, de 13 de noviembre de 2015) no operen mecanismos secundarios para la asistencia gratuita del demandante que lo necesite, especialmente la institución del abogado de turno.

99 Algunos de éstos son: casos en que el Tribunal ha fijado como punto de prueba la "intención de discriminar" a pesar de que aquello es un asunto de calificación jurídica, no un asunto fáctico acreditable (Juzgado de Letras en lo Civil $\left(3^{\circ}\right)$ de Concepción, Rol N ${ }^{\circ} \mathrm{C}-407-2015$, de 13 de julio de 2015); o casos en que se ha establecido como relevante la acreditación de una discriminación "reiterada", a pesar de que la "reiteración" no es algo exigido por la ley (Juzgado de Letras en lo Civil $\left(22^{\circ}\right)$ de Santiago, Rol N ${ }^{\circ} \mathrm{C}-20750-2012$, de 25 de junio de 2013). A estos, se suman problemas de carácter estructural, como, podría ser, aquellos inconvenientes derivados del estándar de la prueba que se debe aplicar por el juez para tener por acreditado un hecho. Véase Díaz (2017), pp. $455-460$.

100 Cabe señalar que el Derecho Procesal moderno ha logrado importantes avances sobre los asuntos probatorios del proceso, lo que ha permitido distinguir con claridad, entre otras cosas, la existencia de una carga de la prueba objetiva (dirigida al juez, y que le entrega una pauta para resolver ante la insuficiencia probatoria, de la que derivará una consecuencia contra una de las partes), y una carga de la prueba subjetiva (que busca influir en la conducta de las partes, indi- 
De la revisión jurisprudencial realizada, se puede apreciar una tendencia mayoritaria por resolver el asunto en base a una lógica "civilista", haciendo aplicable el artículo 1698 del Código Civil (lo que se sustentaría por la regla de supletoriedad del artículo 14 de la Ley). Esta idea hace recaer la carga de la prueba inicialmente en el demandante y, sólo en caso de que éste logre acreditar los supuestos de su demanda, adquirirá relevancia la prueba que ofrezca el demandado para acreditar la razonabilidad de su actuar, o desacreditar los supuestos fácticos de la acción interpuesta en su contra ${ }^{101}$.

Esta lógica es compleja desde la perspectiva del derecho antidiscriminatorio, pues "[u]no de los aspectos más problemáticos en los juicios de discriminación lo constituye la prueba, principalmente por cuanto la acreditación de un hecho discriminatorio puede ser muy difícil (en ocasiones son sólo dichos o expresiones sin mayor materialidad). En efecto, la jurisprudencia analizada demuestra que, en un gran número de casos, los tribunales rechazan la denuncia de discriminación por no haberse acreditado suficientemente los hechos"102. Esto ha demostrado que la forma en que ha sido regulada la carga de la prueba es un factor de extrema relevancia para la efectividad de la acción ${ }^{103: ~ "[t] o d a ~ e s t a ~ s i t u a c i o ́ n ~ d e ~}$

cando quien tiene que aportar ciertas pruebas).

101 Se debe observar que, en materia de procedimientos destinados a la protección de derechos humanos, como ocurre en el proceso seguido ante la Corte Interamericana de Derechos Humanos, la regla general en materia de carga de prueba será contraria a la adoptada por el legislador para la acción de no discriminación arbitraria, privilegiándose una facultad de la Corte para invertir, si lo estima pertinente, la carga de la prueba. Al respecto, véase PAúl DíAz (2015), pp. 307-312.

102 Díaz (2017), p. 469.

103 De la Historia de la Ley $N^{\circ} 20.609$, se podría concluir que los problemas ocasionado por la "desregulación" de la carga de la prueba en éste procedimiento estarían ligado a la truncada (por ahora) reforma al Código de Procedimiento Civil: "Por otra parte, ayer, en la Comisión de Constitución aprobamos en general el proyecto que crea un nuevo Código Procesal Civil, el cual, en el ánimo de modernizar nuestra legislación civil, incorpora la carga de la prueba dinámica, lo que le permite al juez establecer a cuál de las partes le va a corresponder probar el hecho que se alega. Nos parece una de las innovaciones más poderosas y potentes que trae el proyecto presentado por el Ejecutivo. En la iniciativa que hoy nos ocupa, se debería hacer referencia a aquello, porque un ámbito en el que la prueba dinámica puede ser útil es el de la lucha contra la discriminación. Nos parece que es un perfeccionamiento posible y coherente de realizar ahora. Me decía un entendido que, en Estados Unidos, sin la carga de la prueba dinámica como institución en el marco de los juicios por discriminación, sería imposible para muchos probar que han 
imposibilidad o extrema dificultad probatoria en que se encuentra la parte sobre quien recae la carga de la prueba originariamente, podría generar que las partes optaran por desistir de hacer valer sus pretensiones, evitando el riesgo que implica el asumir el inicio de un juicio por los costos económicos y pérdidas de tiempo que ello implica"104.

Una de las alternativas que ha surgido desde la doctrina para abordar esta problemática es la consagración de la "prueba de apariencias" o "prueba de indicios"105, en donde el demandante no estará compelido a presentar una prueba que acredite fehacientemente la responsabilidad del demandado, sino que le bastará con ofrecer un relato y medios probatorios que creen indicios o presunciones suficientes sobre la veracidad de los hechos que sustentan su acción. Por su parte, el demandado tampoco deberá ofrecer una prueba de lo contrario, sino que le bastará con construir una contraprueba que sustente mejores indicios sobre lo ocurrido. Así, el problema dado por la difícil posición del demandante de acreditar ciertos hechos se superaría mediante aligeramientos de la prueba, que permiten al juez dar la razón a una de las partes, gracias a los indicios que ésta aportó, sin exigirle más debido a que se considerará justa su pretensión, pese a la escasez de la prueba ${ }^{106}$.

De esta manera, la "prueba de indicios" no conlleva mayores variaciones formales respecto de otros procedimientos, sino que el sistema probatorio será el mismo que en el resto de los conflictos jurídicos (no ofrece alteraciones a las reglas sobre la carga subjetiva de la prueba o

sido objeto de discriminación, porque la información y los antecedentes obran en poder de la parte contraria" (Discusión en Sala de fecha 4 de abril de 2012, Cámara de Diputados, Historia de la Ley $\mathrm{N}^{\circ} 20.609$, pp. 568-569).

Así, se podría inferir que el legislador, conscientemente, habría optado por no regular expresamente la carga de la prueba en el procedimiento de la Ley $\mathrm{N}^{\circ} 20.609$, pues suponía que el nuevo Código Procesal Civil se encargaría de instaurar nuevas reglas al respecto (de hecho, el artículo 294 del proyecto de Código Procesal Civil establece un nuevo régimen sobre la forma de distribuir la carga de la prueba entre los litigantes). Sin embargo, al día de hoy dicha reforma no se ha materializado en una nueva ley, lo que ha afectado el éxito de la remisión normativa planificada.

104 GIL (2010), p. 71.

105 Entre los autores que consideran esta alternativa como válida, véase la opinión de VIAL (2018).

106 NieVA (2011), pp. 98-99. 
los medios probatorios), pero permitirá al juez aplicar las consecuencias jurídicas negativas de la insuficiencia probatoria, a la parte demandada que no logró destruir los indicios ofrecidos por el actor ${ }^{107}$. El ordenamiento jurídico nacional no es ajeno a esta forma de regular la carga de la prueba, tal como lo apreciaremos, por ejemplo, en el artículo 493 del Código del Trabajo, referido al procedimiento de tutela laboral de derechos fundamentales ${ }^{108}$.

Cabe mencionar, de todas formas, que la implementación legislativa de una prueba de indicios requiere, por cierto, una modificación al inciso tercero del artículo $2^{\circ}$ de la Ley $\mathrm{N}^{\circ} 20.609$, ya que, conforme su tenor actual, la normativa permitiría defender la existencia de una "presunción de razonabilidad"109 en favor de ciertos actos del demandado (ejecutados en ejercicio legítimo de un derecho fundamental u otra razón constitucionalmente legítima), la que, en la práctica, entrega al demandante la carga de presentar pruebas suficientes -no simples indicios-, que sean capaces de destruir aquella "presunción" que la Ley instaura en favor del demandado. De hecho, esta presunción en favor del demandado ha permitido a algunos autores críticar la técnica legislativa empleada, al punto de afirmar que "pareciera ser que estamos frente a una jerarquía de derechos, ya que si la discriminación se produce a consecuencia del ejercicio de otro derecho, aquélla no será arbitraria sino razonable y permitida por el ordenamiento jurídico. En otras palabras, el derecho a no ser discriminado arbitrariamente cedería frente a la invocación de cualquier otro derecho fundamental. Tal jerarquización excedería las competencias del legislador, el cual no puede crear rígidas priorizaciones entre derechos

107 De este modo, es perfectamente posible que no sea necesario aplicar la regla de la prueba de indicios cuando el demandante logre acreditar el acto discriminatorio mediante la aportación de prueba directa, o el demandado pueda acreditar la existencia de un actuar razonable o una contraprueba fáctica. En estos casos, no hay incertidumbre, y, por ende, necesidad de aplicar la "prueba de indicios". Así, sólo en ausencia de una de estas hipótesis, el costo del hecho incierto o dudoso deberá ser soportado por el demandado. UgaRTE (2009), pp. 220 y 222.

108 Artículo 493 del Código del Trabajo: "Cuando de los antecedentes aportados por la parte denunciante resulten indicios suficientes de que se ha producido la vulneración de derechos fundamentales, corresponderá al denunciado explicar los fundamentos de las medidas adoptadas y de su proporcionalidad".

109 Véase al respecto DíAz (2013), pp. 284-285. 
de rango constitucional"110.

Ahora bien, por otro lado, la jurisprudencia nacional ha revisado la posibilidad de utilizar un mecanismo que implique derechamente la inversión de la carga de la prueba ${ }^{111}$, que sería una segunda alternativa para abordar la cuestión probatoria. En este sentido, es interesante revisar un fallo de la Corte de Apelaciones de La Serena, que dictaminó: "Que por lo demás si se considerase que en la especie existe una completa insuficiencia probatoria que impide simplemente dar por probado hecho alguno, correspondería imponer las consecuencias de la falta de prueba a los actores en tanto ellos soportaban la carga de probar al menos el hecho constitutivo de su demanda tantas veces referido, no existiendo norma alguna que permita entender alterada esta regla básica del Derecho procesal, además expresamente prevista en nuestro Derecho en el artículo 1698 del Código Civil.

En efecto, lo precedente no es sino la aplicación de la regla que establece que el peso de la prueba de los hechos constitutivos de la pretensión lo deben soportar los actores, y consecuentemente son estos los que deben asumir las consecuencias procesales adversas frente a una eventual insuficiencia probatoria al respecto.

Cabe plantearse, por último, si el juzgador podía llegar a alterar o modificar la regla de carga probatoria explicada o entender aplicable una diversa, atendida la naturaleza del asunto de que se trata, en cuanto está referida a la tutela de derechos fundamentales y no a la tutela de derechos subjetivos en el ámbito del Derecho privado. Y lo cierto es que habrá de convenirse en que una cosa como la indicada no parece en general plausible, salvo cuando el legislador procesal contemple algún régimen específico en que la regla esencial de carga subjetiva de la prue-

110 Díaz (2017), 2017, pp. 462-465.

111 Podemos entender por "inversión de la carga de la prueba" a aquella regla de distribución de la carga de la prueba mediante la cual, la ley o la jurisprudencia, atribuyen dicha carga a quien no le correspondería normalmente. De esta manera, al invertirse la carga, será el demandado el que tiene que probar la inexistencia de su responsabilidad, pese a que el demandante no haya demostrado en absoluto que tal responsabilidad existe -ni siquiera indicios de ella-. Nieva (2011), pp. 98-99. 
ARTÍCULOS DE INVESTIGACIÓN

ba pueda verse modificada o contemple algunas presunciones específicamente destinadas a eximir de la carga de la prueba respecto de algún hecho que pueda ser invocado con ocasión del planteamiento de una pretensión procesal específica (...)"112.

Esta sentencia abre la discusión sobre la pertinencia de un procedimiento judicial que contemple un régimen de carga dinámica de la prueba ${ }^{113}$-tal como ocurre en España ante discriminaciones por razón de sexo ${ }^{114}$-, el que podría llegar a ser mucho más garantista que un procedimiento sustentado sobre las reglas del derecho privado, como ocurre hoy en día ${ }^{115}$.

Sin embargo, como bien observa el considerando citado, la procedencia de una carga dinámica de la prueba o de un régimen basado en la prueba de indicios, no es un asunto que pueda entregarse a la decisión del juez, debiendo ser el legislador el encargado de tomar esta determinación y concretarla en una regulación específica (más aún si la decisión se decanta en entregar ciertas competencias excepcionales al órgano jurisdiccional $\left.{ }^{116}\right)$. También debe señalarse que una eventual modificación a la regulación actual de la carga de la prueba debería ir acompañado

112 Corte de Apelaciones de La Serena, Rol N C-639-2014, de 28 de agosto de 2014, considerando $9^{\circ}$.

113 La carga dinámica de la prueba "tiende a justificar, para los casos excepcionales en que corresponde aplicarla, que se libere total o parcialmente al litigante constreñido a probar según las normas clásicas y aun modernas sobre el onus probandi, para trasladar y desplazar sobre el demandado dicho esfuerzo verificatorio cuando se halla en mejor disponibilidad de los medios de prueba. Se le imputa a éste, al menos, el deber de colaboración en busca de una eficiente administración de justicia". PALOMO (2013), p. 457.

114 Artículo 217.5 de la Ley de Enjuiciamiento Civil española: "De acuerdo con las leyes procesales, en aquellos procedimientos en los que las alegaciones de la parte actora se fundamenten en actuaciones discriminatorias por razón del sexo, corresponderá al demandado probar la ausencia de discriminación en las medidas adoptadas y de su proporcionalidad.

A los efectos de lo dispuesto en el párrafo anterior, el órgano judicial, a instancia de parte, podrá recabar, si lo estimase útil y pertinente, informe o dictamen de los organismos públicos competentes".

115 De todas formas, esta opinión posee detractores (véase PALOMO [2013], pp. 457-459), y autores que estiman que la "prueba de indicios" y las que conllevan una inversión de la carga probatoria, como son las cargas dinámicas, no tendrían diferencias prácticas, pues en ambas se exigiría al demandante un ejercicio probatorio, aunque sea mínimo, para la comprobación de la seriedad de la acción (véase NieVA [2011], pp. 99-101).

116 Además, así se desprende de los artículos $7^{\circ}$ y $19 N^{\circ} 3$ de la Constitución Política. 
de mecanismos que desincentiven la proliferación de demandas falsas o extremadamente temerarias (tal vez con una regulación expresa sobre el régimen de las costas en el procedimiento, o una aclaración sobre la procedencia de las multas contra el demandante).

f) Sobre el derecho al recurso, el artículo 13 inciso segundo de la Ley N²0.609 contempla la posibilidad de impugnación de resoluciones judiciales, diciendo: "La sentencia definitiva, la resolución que declare la inadmisibilidad de la acción y las que pongan término al procedimiento o hagan imposible su prosecución serán apelables, dentro de cinco días hábiles, para ante la Corte de Apelaciones que corresponda, ante la cual no será necesario hacerse parte".

A esto se suma que, en virtud de la remisión del artículo 14 de la Ley N²0.609 al Libro I del Código de Procedimiento Civil, también serían procedente los recursos de reposición, de hecho y el de aclaración, rectificación y enmienda ${ }^{117}$.

Es, tal vez, la admisibilidad del recurso de casación el asunto más debatible debido a que no existe remisión expresa a sus reglas, sin embargo cada vez hay más casos en los que la Corte Suprema ha aceptado su procedencia $^{118}$ (e incluso ha declarado casaciones de oficio ${ }^{119}$ ). Contrario a ello es la experiencia sobre la admisión de recursos de queja, puesto

117 Sin perjuicio, existe jurisprudencia que establece una opinión contraria: "4) Que, al tenor de las normas transcritas, aparece que el estatuto especial que regula este tipo de procedimiento busca que la acción deducida en caso de discriminaciones arbitrarias tenga una tramitación rápida, en razón de la materia discutida (...). 5) Que, a mayor abundamiento, el artículo 14 del citado cuerpo legal sólo limita la remisión al Código de Procedimiento Civil a lo referido a 'la sustanciación de la acción', expresión que, a juicio de esta Corte, no incluye lo relativo al régimen recursivo, para lo cual existe norma expresa en el artículo anterior". Corte Suprema, Rol N ${ }^{\circ} \mathrm{C}-33156-2015$, de 11 de enero de 2016 , considerandos $4^{\circ}$ y $5^{\circ}$.

118 Ejemplo de ello son los fallos Corte Suprema, Rol N ${ }^{\circ} \mathrm{C}-2847-2017$, de 23 de octubre de 2017; Corte Suprema, Rol N ${ }^{\circ} \mathrm{C}-38521-2017$, de 21 de junio de 2018; Corte Suprema, Rol $\mathrm{N}^{\circ} \mathrm{C}$ 5098-2017, de 3 de julio de 2018; y Corte Suprema, Rol N ${ }^{\circ} \mathrm{C}-41388-2017$, de 25 de julio de 2018. De hecho, al declarar la inadmisibilidad de un recurso de queja deducido contra una sentencia definitiva de segunda instancia, la Corte expresamente reconoció: "(...) La sentencia de segundo grado antes mencionada tiene el carácter de definitiva, susceptible por ende de ser impugnada por la vía del recurso de casación, lo que excluye el arbitrio ejercitado en autos" (Corte Suprema, Rol N ${ }^{\circ} \mathrm{C}-22359-2014$, de 2 de septiembre de 2014, considerando $2^{\circ}$ ).

119 Por ejemplo, Corte Suprema, Rol N ${ }^{\circ}$-38238-2016, de 19 de diciembre de 2017; y Corte Suprema, Rol N ${ }^{\circ} \mathrm{C}-41388-2017$, de 25 de julio de 2018. 
que no hay constancia de que alguno haya sido aceptado por la máxima judicatura nacional ${ }^{120}$.

g) Finalmente, respecto del principio de proporcionalidad y de la motivación de la sentencia, la directa aplicación del artículo $170 \mathrm{~N}^{\circ} 4$ del Código de Procedimiento Civil no dejaría lugar a duda a que el fallo definitivo deberá consignar los fundamentos de hecho y de derecho gracias a los cuales el juez adopta su decisión.

Sin embargo, respecto de la técnica utilizada para encontrar una solución al conflicto, no nos parece acertada la exigencia de un test o de criterios de análisis estrictos, considerándose suficiente la utilización de un baremo de control basado en la "razonabilidad" del acto o, a contrario sensu, su falta de "arbitrariedad"121. Por ello se ve con ojos positivos la existencia -minoritaria- de fallos en que el Juez resuelve verificando si existió o no un fundamento racional en el actuar del demandado ${ }^{122}$. Lamentablemente, la mayoría de los casos carecen de desarrollo y de mayores argumentaciones, entregando pocos considerandos para abordar el asunto de fondo, sumado a que en ellos pocas veces existe una utilización de los conceptos del derecho antidiscriminatorio, debido, tal vez, al carácter de "reciente" que tiene esta disciplina dentro de la praxis judicial nacional.

\section{Conclusión}

La tutela judicial efectiva como derecho fundamental, implica que la legislación destinada a la materialización de los procedimientos judiciales

120 Ya que la Corte Suprema ha sido contundente al declarar inadmisible los recursos de quejas presentados contra la sentencia que resuelve un recurso de apelación en segunda instancia (Corte Suprema, Rol N ${ }^{\circ} \mathrm{C}-30591-2014$, de 31 de diciembre de 2014 y Corte Suprema, Rol N ${ }^{\circ} \mathrm{C}$ 8855-2015, de 22 de julio de 2015), así como aquellos presentados contra las resoluciones que fallan un recurso de reposición (Corte Suprema, Rol N ${ }^{\circ} \mathrm{C}-41318-2017$, de 24 de octubre de 2017).

121 Un estudio al respecto puede encontrarse en DíAz (2017), pp. 476-479.

122 Sin embargo, es posible encontrar fallos que van más allá, y aplican criterios más estrictos como el conocido test de proporcionalidad (ejemplo, Juzgado de Letras en lo Civil $\left(17^{\circ}\right)$ de Santiago, Rol $N^{\circ} \mathrm{C}-27742-2016$, de 31 de julio de 2017). Para comprender las diferencias entre el test de racionalidad y el test de proporcionalidad como herramientas para examinar si una diferencia de trato constituye o no una diferencia arbitraria que deba ser repudiada por el derecho, véase DíAz (2019), pp. 93-100. 
que velen por la resolución de conflictos deban satisfacer un estándar sustancial mínimo, pues es sobre la protección y respeto a los derechos fundamentales donde se instalarán los pilares de una sociedad democrática sana.

Como hemos podido revisar, este estándar sustancial que da forma al contenido esencial del derecho a la tutela judicial efectiva, se compone de tres elementos: la efectividad de la decisión judicial; el acceso a la justicia; y el debido proceso. Estos elementos deben ser el farol que guíe al legislador al momento de estructurar un mecanismo jurisdiccional -general o especial- destinado a proteger derechos e intereses, velando por el cumplimiento del ordenamiento jurídico cuando aquel no es acatado voluntariamente por los miembros de la sociedad. De esta forma, el estándar sustancial será el cristal básico por el cual observar nuestros procedimientos judiciales, y en base a esto, comprobar su concordancia con los valores y principios que rigen a un Estado de Derecho moderno.

El objetivo de la presente investigación fue someter a dicho examen al procedimiento especial contenido en la Ley Zamudio, que instaura la acción de no discriminación arbitraria.

Respecto del primero de los elementos, pudimos comprobar la existencia de graves problemas respecto de la efectividad de la acción, pues los jueces civiles son muy reacios a ejercer las potestades relevantes que la ley les entrega para el restablecimiento del imperio del derecho, siendo muy excepcional que el Tribunal ordene a algo más que el simple "cese" del acto que provoca la discriminación.

Esta crítica se extiende a la decisión del legislador para no permitir demandar indemnizaciones de perjuicios (o facilitar su reclamo en un juicio posterior). A pesar de que se puedan considerar loables las motivaciones para esta prohibición, lo cierto es que por la naturaleza del acto discriminatorio será difícil resguardar a la víctima a través de una simple declaración de discriminación o la imposición de una sanción patrimonial a beneficio fiscal. Puede que la solución no sea la indemnización de perjuicios como tal, pero el legislador debiera de pensar una mejor alternativa que la simple multa a beneficio fiscal, tal como lo ha realizado en otras acciones especiales, como aquella contenida en la Ley $N^{\circ} 19.779$. 
Por su parte, sobre el acceso a la jurisdicción también pudimos apreciar la existencia de trabas que merman el sentido que busca impulsar el derecho antidiscriminatorio. La existencia de una legitimación activa "restrictiva", que impide a agrupaciones litigar contra acciones discriminatorias (fomentando un sentido "individualista" del derecho antidiscriminatorio), o liberar sólo al demandado de la carga del patrocinio de abogado, dan cuenta de una limitación innecesaria ante situaciones que, a la larga, también nos afectan como sociedad, entendiendo que la "no discriminación arbitraria" apunta, en definitiva, a mejorar las relaciones entre conciudadanos.

Sin embargo, el aspecto que contradice de forma más clara a la tutela judicial efectiva, se encontrará en la deficiente regulación sobre las cargas probatorias (que es uno de los elementos del debido proceso). Claramente, la generalidad de los hechos que constituyen un trato discriminatorio son de difícil acreditación por su fugacidad (un insulto, por ejemplo), o por acreditarse mediante prueba encontrada en poder del victimario, transformándose esta barrera en un elemento insalvable para las víctimas, provocando que, en la mayoría de la jurisprudencia que rechaza la acción se use como fundamento principal la "falta de acreditación" de los hechos o de los actos discriminatorios. Estudiar las opciones existentes al respecto, como la carga dinámica de la prueba o la prueba de indicios, puede ser la vía para que la acción sea de mayor utilidad para los miembros de la sociedad que sufren de una discriminación.

Este tipo de críticas fomentan las voces que la han catalogado de insuficiente a la Ley Zamudio ante los estándares de una sociedad moderna, especialmente si, paralelamente, encontramos otras acciones que no cuentan con tantas críticas por contradecir el estándar mínimo que impone la tutela judicial efectiva, como son las acciones de protección o la tutela de derechos fundamentales del artículo 485 y siguientes del Código del Trabajo (que, conoce vulneraciones al artículo $2^{\circ}$ del código laboral, donde se reconoce el principio de no discriminación laboral), las que, además, cuentan con una tradición jurisprudencial asentada, que refleja una idoneidad tutelar.

Creemos, para finalizar, que una reforma a la Ley $\mathrm{N}^{\circ} 20.609$, especial- 
mente al procedimiento por el cual se conoce la acción de no discriminación arbitraria, poco a poco se volverá urgente, pues el riesgo latente de que la práctica jurídica termine sepultando la utilidad de la acción, volviéndola inoficiosa (más aún frente a la posibilidad cierta de optar por otras acciones), se puede terminar traduciendo en un fracaso del aspecto jurisdiccional de la primera Ley General contra la Discriminación del país.

\section{Bibliografía}

Aldunate Lizana, Eduardo (2008): Derechos Fundamentales (Santiago, Chile, Legal Publishing).

Alvarado Velloso, Adolfo (2013): El Proceso Judicial (Lima, Perú, Editorial San Marcos).

Aróstica Maldonado, Iván (2008): "Los Contenciosos Administrativos Especiales en la Legislación Chilena”, en Ius Publicum, Universidad Santo Tomás (N²0), pp. 85-103.

Bernales Rojas, Gerardo (2019): Acceso a la Justicia y Debido Proceso (Porto, Portugal, Editorial Juruá).

Bordalí Salamanca, Andrés (2011): "Análisis Crítico de la Jurisprudencia del Tribunal Constitucional sobre el Derecho a la Tutela Judicial”, en Revista Chilena de Derecho, Pontificia Universidad Católica de Chile (vol.38, N²), pp. 311-337.

Bordalí Salamanca, Andrés (2016): Derecho Jurisdiccional (Valdivia, Chile, Ediciones Universidad Austral de Chile).

Candia Falcón, Gonzalo (2017): "El Estado de Derecho: ¿al Servicio de los Derechos Fundamentales?", en Revista de Derecho, Universidad Austral de Chile (vol. XXX, N²), pp. 181-201.

Casas Becerra, Lidia y Lagos Tschorne, Catalina (2014): "Análisis Crítico de la Acción de No Discriminación Arbitraria a la Luz de los Primeros Casos", en Anuario de Derechos Humanos, Universidad de Chile (N¹0), pp. 127-137.

Cazor Aliste, Kamel (2001): "Democracia y Constitución en Chile", en Revista de Derecho, Universidad Católica de Valparaíso (vol. XXII), pp. 279-293. 
Cea Egaña, José Luis (2012): Derecho Constitucional Chileno (Santiago, Chile, Ediciones Universidad Católica de Chile, $2^{\mathrm{a}}$ edición actualizada), tomo II.

Colombo Campbell, Juan (1991): La Jurisdicción en el Derecho Chileno. Un Aporte al Estudio del Conflicto y sus Formas de Solución (Santiago, Chile, Editorial Jurídica de Chile).

Conget Morral, Josefa de Jesús (2015): La Prueba como Garantía Mínima dentro del Debido Proceso (memoria para optar al grado de Licenciado en Ciencias Jurídicas y Sociales, Universidad de Chile).

Díaz de VAldés JulíA, José Manuel (2013): "¿Es la Ley Zamudio Verdaderamente una Ley General Antidiscriminación?”, en Revista Actualidad Jurídica, Universidad del Desarrollo ( $\left.{ }^{\circ} 28\right)$, pp. 279-297.

Díaz dE VAldés JuliÁ, José Manuel (2017): "Cuatro Años de la Ley Zamudio: Análisis Crítico de su Jurisprudencia”, en Estudios Constitucionales, Universidad de Talca (vol.15, №2), pp. 447-488.

DíaZ dE VAldÉs JuliÁ, José Manuel (2018): "Análisis Cuantitativo de la Acción Especial Antidiscriminación de la Ley Zamudio", en Revista Actualidad Jurídica, Universidad del Desarrollo ( $\left.N^{\circ} 38\right)$, pp. 15-33.

Díaz de VALdÉs JuLIÁ, José Manuel (2019): Igualdad Constitucional y No Discriminación (Valencia, España, Tirant lo Blanch).

FerRAJoli, Luigi (2016): Los Derechos y sus Garantías. Conversación con Mauro Barberis (tradución por José Manuel Revuelta, Madrid, España, Editorial Trotta).

FerRAjolı, Luigi (2019): Derechos y Garantías. La Ley del Más Débil (tradución por Perfecto Andrés IBÁÑEZ y Andrea GrePPI, Madrid, España, Editorial Trotta, $8^{\mathrm{a}}$ edición).

Fioravanti, Maurizio (2000): Los Derechos Fundamentales. Apuntes de Historia de las Constituciones (traducción por Manuel Martínez NeIRA, Madrid, España, Editorial Trotta, $3^{\mathrm{a}}$ edición).

GARCIA MÁYNEZ, Eduardo (2002): Introducción al Estudio del Derecho (Distrito Federal, México, Editorial Porrua, 53 edición).

García Pino, Gonzalo y Contreras VÁsquez, Pablo (2013): "El Derecho a la Tutela Judicial y al Debido Proceso en la Jurisprudencia del Tribunal Constitucional Chileno", en Estudios Constitucionales, Universidad de 
Talca (vol.11, N²), pp. 229-282.

GIL Seaton, Ayllen (2010): "Cargas Probatorias Dinámicas. Una Solución ante la Dificultad Probatoria", en Revista de Estudios lus Novum, Pontificia Universidad Católica de Valparaíso ( $\mathrm{N}^{\circ} 3$ ), pp. 63-86.

GoRnIG, Gilbert (2010): "Los Derechos Fundamentales: Alcance, Orígen, Funciones y Aplicación", en A.A.V.V., La Ley Fundamental Alemana y la Constitución Política Chilena. Estudio Constitucional Comparado (Santiago, Chile, Editorial Jurídica de Chile), pp. 41-82.

HESSE, Konrad (2001): "Significado de los Derechos Fundamentales", en LóPEZ PIÑA, Antonio (editor), Manual de Derecho Constitucional (Madrid, España, Marcial Pons Ediciones Jurídicas y Sociales), pp. 83-115. Holmes, Stephen y Sunstein, Cass (2011): El Costo de los Derechos: Por Qué la Libertad depende de los Impuestos (traducción por Stella MASTRANGelo, Buenos Aires, Argentina, Siglo Veintiuno Editores).

LetURIA Infante, Francisco Javier (2018): "Las Acciones Cautelares y el Recurso de Protección ¿Es Necesaria una Duplicidad de Instituciones? Notas para una Mejor Garantía de los Derechos Fundamentales", en Estudios Constitucionales, Universidad de Talca (vol.16, №1), pp. 227-244.

LewIS RIPolL, Sebastián (2014): "La Regla Solve et Repete en Chile", en Estudios Constitucionales, Universidad de Talca (vol.12, N²), pp. 239-272.

López Masle, Julián (2006): "Debido Proceso en Chile: Hacia un Principio Generador de Reglas", en Bordalí Salamanca, Andrés (editor), Justicia Constitucional y Derechos Fundamentales (Santiago, Chile, LexisNexis), pp. 181-207.

Lovera PARMo, Domingo (2017): "Destinatarios de los Derechos Fundamentales", en Contreras Vásquez, Pablo y Salgado Muñoz, Constanza (editores), Manual sobre Derechos Fundamentales (Santiago, Chile, LOM Ediciones), pp. 161-206.

Martínez Benavides, Patricio (2012): "El Principio de Inexcusabilidad y el Derecho de Acción desde la Perspectiva del Estado Constitucional", en Revista Chilena de Derecho, Pontificia Universidad Católica de Chile (vol.39, N¹), pp. 113-147. 
Montero Aroca, Juan, Gómez Colomer, Juan Luis y Barona Vilar, Silvia (2018): Derecho Jurisdiccional. Parte General (Valencia, España, Tirant lo Blanch, $26^{a}$ edición), tomo I.

Montero Aroca, Juan, Gómez Colomer, Juan Luis, Montón Redondo, Alberto y Barona Vilar, Silvia (2005): Derecho Jurisdiccional. Parte General (Valencia, España, Tirant lo Blanch, 14ª edición), tomo I.

MuÑoz León, Fernando (2015): “Estándares Conceptuales, Cargas Procesales y Reparación en el Litigio Antidiscriminación. Análisis Crítico de la Jurisprudencia sobre Ley Zamudio entre 2012 a 2015", Inédito, pp. 1-33.

Nieva-FenolL, Jordi (2011): "Los Sistemas de Valoración de la Prueba y la Carga de la Prueba: Nociones que Precisan Revisión”, en Justicia: Revista de Derecho Procesal, Editorial Bosch (N³-4), pp. 91-120.

Nogueira AlcalÁ, Humberto (2003): Teoría y Dogmática de los Derechos Fundamentales (Distrito Federal, México, Universidad Nacional Autónoma de México).

Nogueira Alcalá, Humberto (2007): El Debido Proceso en la Constitución y el Sistema Interamericano (Santiago, Chile, Librotecnia).

Nogueira AlcalÁ, Humberto (2008): Derechos Fundamentales y Garantías Constitucionales (Santiago, Chile, Librotecnia), tomo II.

Nogueira Alcalá, Humberto (2010): Derechos Fundamentales y Garantías Constitucionales (Santiago, Chile, Librotecnia, $3^{a}$ edición), tomo I. Orellana Torres, Fernando (2009): Manual de Derecho Procesal. Procedimientos Civiles Ordinarios y Especiales (Santiago, Chile, Librotecnia, $3^{a}$ edición actualizada), tomo II.

Pacheco llabacA, Fabián y Reyes López, Jaqueline (2019): Análisis Jurisprudencial del Tribunal Constitucional de Chile y la Corte Interamericana de Derechos Humanos, Respecto a los Elementos del Debido Proceso (Santiago, Chile, Ediciones Jurídicas de Santiago).

Palomo Vélez, Diego (2013): "Las Cargas Probatorias Dinámicas: ¿Es Indispensable Darse Toda Esta Vuelta?”, en Revista lus et Praxis, Universidad de Talca (vol.19, N²), pp. 447-464.

Paredes Paredes, Felipe (2014): La Garantía Jurisdiccional de los Derechos Fundamentales (Santiago, Chile, Thomson Reuters). 
Paúl Diaz, Álvaro (2015): "Análisis Sistemático de la Evaluación de la Prueba que Efectúa la Corte Interamericana de Derechos Humanos", en Revista Chilena de Derecho, Pontificia Universidad Católica de Chile (vol.42, N¹), pp. 297-327.

Pereira Menaut, Antonio-Carlos (2006): Teoría Constitucional (Santiago, Chile, Lexis Nexis, $2^{\mathrm{a}}$ edición).

Pérez Luño, Antonio (2004): Los Derechos Fundamentales (Madrid, España, Editorial Tecnos, $8^{\text {a }}$ edición).

Pıcó I Junor, Joan (2011): Las Garantías Constitucionales del Proceso (Barcelona, España, Editorial Bosch, $2^{\mathrm{a}}$ edición).

Rodriguez Grez, Pablo (2013): "Sobre Discriminación Arbitraria", en Revista Actualidad Jurídica, Universidad del Desarrollo (N²8), pp. 187-205. Romero Seguel, Alejandro (2014a): Curso de Derecho Procesal Civil. La Acción y la Protección de los Derechos (Santiago, Chile, Thomson Reuters, $2^{\mathrm{a}}$ edición actualizada), tomo I.

Romero Seguel, Alejandro (2014b): Curso de Derecho Procesal Civil. Los Prespuestos Procesales Relativos al Órgano Jurisdiccional y a las Partes (Santiago, Chile, Thomson Reuters, $2^{\mathrm{a}}$ edición actualizada), tomo II.

Rosales Rigol, Cecilia (2014): "La Acción de No Discriminación Arbitraria", en Silva Gallinato, María Pía y Henríquez Viñas, Miriam (editoras), Acciones Protectoras de Derechos Fundamentales (Santiago, Chile, Legal Publishing-Thomson Reuters), pp. 256-295.

Sото KLoss, Eduardo (1982): El Recurso de Protección. Orígenes, Doctrina y Jurisprudencia (Santiago, Chile, Editorial Jurídica de Chile).

Squella NARducCl, Agustín (2011): Introducción al Derecho (Santiago, Chile, Editorial Jurídica de Chile, $2^{\mathrm{a}}$ edición actualizada y ampliada). Ugarte Cataldo, José Luis (2009): "Tutela Laboral de Derechos Fundamentales y Carga de la Prueba", en Revista de Derecho, Universidad Católica de Valparaíso (vol. XXXIII, segundo semestre), pp. 215-228. VIAL SolAR, Tomás (2018). "Ley Antidiscriminación: ¿Llegó el Tiempo de Revisarla?", [fecha de consulta: 10 de agosto de 2018]. [Disponible en: http://www.elmercurio.com/Legal/Noticias/Opinion/2018/08/02/ Ley-Antidiscriminacion-llego-el-tiempo-de-revisarla.aspx]. 
Vivanco Martínez, Ángela (2006): Curso de Derecho Constitucional (Santiago, Chile, Ediciones Universidad Católica de Chile, $2^{\mathrm{a}}$ edición ampliada), tomo II.

WALDRON, Jeremy (2005): Derechos y Desacuerdos (traducción por José Luis MARTí y Águida Quiroga, Madrid, España, Marcial Pons).

Williams Benavente, Jaime (1999): Lecciones de Introducción al Derecho (Santiago, Chile, Ediciones Fundación de Ciencias Humanas, $3^{\mathrm{a}}$ edición actualizada).

Zapata Larraín, Patricio (2008): Justicia Constitucional. Teoría y Práctica en el Derecho Chileno y Comparado (Santiago, Chile, Editorial Jurídica de Chile).

\section{Normas Jurídicas Citadas}

Convención Americana de Derechos Humanos (Pacto de San José de Costa Rica).

Constitución Política de la República de Chile.

Código del Trabajo.

Código Orgánico de Tribunales.

Código Procesal Penal.

Ley $\mathrm{N}^{\circ} 20.609$, que establece medidas contra la discriminación. Diario Oficial, 24 de julio de 2012.

Ley $\mathrm{N}^{\circ} 19.779$, que establece normas relativas al virus de inmunodeficiencia humana y crea bonificación fiscal para enfermedades catastróficas. Diario Oficial, 14 de diciembre de 2001.

Ley de Enjuiciamiento Civil (España).

\section{Jurisprudencia Citada}

Tribunal Constitucional de España, 8 de junio de 1981 (recurso de amparo), Rol N¹9/1981.

Control de constitucionalidad respecto del proyecto de ley sobre composición, organización y atribuciones de la Corte Suprema y modificaciones a los recursos de queja y de casación (1995): Tribunal Constitu- 
cional, 31 de enero de 1995 (control de constitucionalidad preventivo), Rol N²05-95.

Requerimiento de inaplicabilidad deducido por Sociedad Ocean Front S.A.,respecto del artículo 107 de la Ley General de Bancos (2008): Tribunal Constitucional, 31 de enero de 2008 (requerimiento de inaplicabilidad por inconstitucionalidad), Rol N811-07.

Requerimiento de inaplicabilidad por inconstitucionalidad presentado por la llustre Municipalidad de Santiago, respecto del artículo $5^{\circ}$ de la Ley $N^{\circ} 17.322$ sobre Normas para la Cobranza Judicial de Cotizaciones, Aportes y Multas de las Instituciones de Seguridad Social (2008): Tribunal Constitucional, 8 de enero de 2008 (requerimiento de inaplicabilidad por inconstitucionalidad), Rol N977-07.

Requerimiento de inaplicabilidad presentado por Hernán Pfeifer Frenz y otros respecto de la segunda frase del inciso primero del artículo 171 del Código Sanitario (2008): Tribunal Constitucional, 3 de enero de 2008 (requerimiento de inaplicabilidad por inconstitucionalidad), Rol N'792-07.

Requerimiento de inaplicabilidad presentado por Patricio Rodrigo Meneses Farías respecto del artículo 230, inciso primero, del Código Procesal Penal (2008): Tribunal Constitucional, 19 de agosto de 2008 (requerimiento de inaplicabilidad por inconstitucionalidad), Rol N815-07. Vera con Medi-Matic S.A. (2012): Juzgado de Letras en lo Civil $\left(12^{\circ}\right)$ de Santiago, 24 de enero de 2012 (juicio ordinario de indemnización de perjuicios), Rol $\mathrm{N}^{\circ} \mathrm{C}-6743-2010$.

Ortiz con Chaguán y otros (2013): Juzgado de Letras en lo Civil $\left(22^{\circ}\right)$ de Santiago, 25 de junio de 2013 (acción de no discriminación arbitraria), Rol N ${ }^{\circ} \mathrm{C}-20750-2012$.

Carvajal con Duarte (2014): Corte Suprema, 31 de diciembre de 2014 (recurso de queja), Rol NC-30591-2014.

Fuentes y Lastra con Complejo Turísitico Costa Barúa Ltda. y otro (2014): Juzgado de Letras en lo Civil de Constitución, 23 de abril de 2014 (acción de no discriminación arbitraria), Rol N C-41-2013.

Larraín con Peñailillo (2014): Juzgado de Letras en lo Civil $\left(1^{\circ}\right)$ de Santiago, 17 de septiembre de 2014 (acción de no discriminación arbitraria), 
Rol N ${ }^{\circ} \mathrm{C}-9118-2014$.

Majmud con Ministerio de Obras Públicas (2014): Juzgado de Letras en lo Civil $\left(4^{\circ}\right)$ de Antofagasta, 30 de junio de 2014 (acción de no discriminación arbitraria), Rol $N^{\circ} \mathrm{C}-5451-2013$.

Majmud con Ministerio de Obras Públicas (2014): Corte Suprema, 2 de septiembre de 2014 (recurso de queja), Rol NC-22359-2014.

Rojas y otros con Instituto Profesional Providencia (2014): Corte de Apelaciones de La Serena, 28 de agosto de 2014 (recurso de apelación), Rol NC-639-2014.

Díaz con Colegio Nuestra Señora del Huerto (2015): Corte Suprema, 22 de julio de 2015 (recurso de queja), Rol N C-8855-2015.

Giacamán con Municipalidad de Concepción (2015): Juzgado de Letras en lo Civil $\left(3^{\circ}\right)$ de Concepción, 13 de julio de 2015 (acción de no discriminación arbitraria), Rol NC-407-2015.

Jiménez con González (2015): Juzgado de Letras en lo Civil de Ancud, 25 de mayo de 2015 (acción de no discriminación arbitraria), Rol $\mathrm{N}^{\circ} \mathrm{C}-210-2015$.

Montt con Corporación de Asistencia Judicial (2015): Juzgado de Letras en lo Civil $\left(1^{\circ}\right)$ de Santiago, 13 de noviembre de 2015 (acción de no discriminación arbitraria), Rol NC-25799-2015.

Requerimiento de inaplicabilidad por inconstitucionalidad presentado por Mariano Saavedra Mora y Asesorías e Inversiones Mass Ltda. respecto del artículo $6^{\circ}$ de la Ley $N^{\circ} 4.287$ (2015): Tribunal Constitucional, $1^{\circ}$ de septiembre de 2015 (requerimiento de inaplicabilidad por inconstitucionalidad), Rol N²701-14.

Requerimiento de inaplicabilidad por inconstitucionalidad presentado por Pablo Duvingelo Alfaro respecto de los artículos 387, inciso primero, del Código Procesal Penal y 158 del Código de Procedimiento Civil (2015): Tribunal Constitucional, $1^{\circ}$ de septiembre de 2015 (requerimiento de inaplicabilidad por inconstitucionalidad), Rol N²802-15.

Soto con Línea de Microbuses $N^{\circ} 4$ (2015): Juzgado de Letras en lo Civil $\left(1^{\circ}\right)$ de Valdivia, 21 de agosto de 2015 (acción de no discriminación arbitraria), Rol ${ }^{\circ} \mathrm{C}-1509-2015$.

Castro con Tercera Compañía de Bomberos de Lautaro (2016): Juzgado 
de Letras y Familia de Lautaro, 29 de febrero de 2016 (acción de no discriminación arbitraria), Rol N ${ }^{\circ} \mathrm{C}-145-2015$.

Covarrubias y otro con León y otro (2016): Juzgado de Letras en lo Civil $\left(1^{\circ}\right)$ de Puente Alto, 26 de agosto de 2016 (acción de no discriminación arbitraria), Rol N ${ }^{\circ} \mathrm{C}-3388-2015$.

García con Municipalidad de La Serena y otro (2016): Juzgado de Letras en lo Civil $\left(2^{\circ}\right)$ de La Serena, 14 de septiembre de 2016 (acción de no discriminación arbitraria), Rol NC-2903-2015.

Ñaguey con Carvajal y Fierro (2016): Corte Suprema, 11 de enero de 2016 (recurso de hecho), Rol N ${ }^{\circ}-33156-2015$.

Requerimiento de inaplicabilidad por inconstitucionalidad presentado por Puertos y Logísticas S.A. respecto del inciso segundo del artículo 768 del Código de Procedimiento Civil (2016): Tribunal Constitucional, 27 de diciembre de 2016 (requerimiento de inaplicabilidad por inconstitucionalidad), Rol N³008-16.

Requerimiento de inaplicabilidad por inconstitucionalidad presentado por Roberto Guzmán Lyon respecto del artículo 29 del D.L. №3.538, de 1980, que crea la Superintendencia de Valores y Seguros (2016): Tribunal Constitucional, 29 de septiembre de 2016 (requerimiento de inaplicabilidad por inconstitucionalidad), Rol N²922-2015.

Bravo con Fantuzzi y otros (2017): Juzgado de Letras en lo Civil (4º de Santiago, 25 de enero de 2017 (acción de no discriminación arbitraria), Rol NC-31281-2016.

Ferrada y otros con Asofamech (2017): Juzgado de Letras en lo Civil $\left(2^{\circ}\right)$ de Valparaíso, 20 de octubre de 2017 (acción de no discriminación arbitraria), Rol NC-304-2016.

García con Municipalidad de La Serena y otro (2017): Corte Suprema, 23 de octubre de 2017 (recurso de casación en el fondo), Rol $\mathrm{N}^{\circ} \mathrm{C}-2847-2017$.

González con Ortúzar y otro (2017): Corte Suprema, 19 de diciembre de 2017 (recurso de casación en el fondo), Rol N C-38238-2016.

Sandoval con Metro S.A. (2017): Juzgado de Letras en lo Civil $\left(29^{\circ}\right)$ de Santiago, 13 de marzo de 2017 (acción de no discriminación arbitraria), Rol N ${ }^{\circ} \mathrm{C}-20679-2016$. 
Ureta con Academia de Fernando González (2017): Juzgado de Letras en lo Civil $\left(17^{\circ}\right)$ de Santiago, 31 de julio de 2017 (acción de no discriminación arbitraria), Rol N${ }^{\circ} \mathrm{C}-27742-2016$.

Villagrán con Aberl (2017): Corte Suprema, 24 de octubre de 2017 (recurso de queja), Rol N ${ }^{\circ} \mathrm{C}-41318-2017$.

García-Huidobro con Colegio Alemán de Puerto Varas (2018): Corte Suprema, 21 de junio de 2018 (recurso de casación), Rol N ${ }^{\circ} \mathrm{C}-38521-2017$. Olivares con Isapre Vida Tres S.A. (2018): Corte Suprema, 3 de julio de 2018 (recurso de casación), Rol NC-5098-2017.

Sandoval con Metro S.A. (2018): Corte Suprema, 25 de julio de 2018 (recurso de casación), Rol Nº ${ }^{\circ}-41388-2017$. 